\title{
ENVIRONMENTAL FAUST SUCCUMBS TO TEMPTATIONS OF ECONOMIC MEPHISTOPHELES, OR, VALUE BY ANY OTHER NAME IS PREFERENCE
}

\author{
Carol M. Rose*
}

The Economy of the Earth: Philosophy, LAW, AND The EnviRONMENT. By Mark Sagoff. Cambridge: Cambridge University Press. 1988. Pp. x, 271. \$29.95.

In several of the chapters to his new book, Mark Sagoff begins by telling some story to frame the remainder. One of these is particularly significant for the book: Sagoff retells a New Yorker joke in which the Devil tells the new entrants to Hell that they are leaving right and wrong behind, and entering a world of mere preferences (p. 99). The Devil signifies for Sagoff the economics-oriented policy analyst, and the story is prophetic because by the end of the book, that old preference-counting Devil has caught up with Sagoff.

The word "environment" appeared in the titles of several of the earlier essays on which the book is based, ${ }^{1}$ but the book has wisely subordinated that E-word to a subtitle; despite the frequent invocation of natural wonders and scenic areas, the book doesn't really focus on the environment until the last chapter. Nope, this book is about that other E-word, Economics, which is so favored by the Devil. More specifically, at least until that last chapter, the book is about how devilishly daffy economists are when they talk about the environment. Sagoff thinks their clever confusions are at best distracting and at worst antidemocratic (pp. 10, 95-97), and if we don't watch out, they are going to lead us off the ethical path and straight down the road to perdition.

Up to the book's end, only an occasional grudging concession ${ }^{2}$ relieves the hellfire-and-brimstone economics-bashing. Consequently, dear Reader, you will be ill-prepared for that last chapter where, lo and behold!, it turns out that the true path to environmental paradise is through tradeable emission rights (pp. 209-10). What? What? Tradeable emission rights have been pushed for years by those diaboli-

* Professor, Northwestern University School of Law. B.A. 1962, Antioch College; M.A. (Political Science) 1963, University of Chicago; Ph.D. (History) 1969, Cornell University; J.D. 1977, University of Chicago. - Ed.

1. P. $x$ (listing earlier history).

2. See, e.g., pp. 71-73. 
cal economists; 3 so you may well put this book down with the thought that somebody has been hoodwinked into a pact with the Devil - or at least that, as with Faust, two souls struggle, ach, within the author's breast.

This book, like Sagoff's work generally, will quite rightly interest many people who are looking for fresh approaches to environmental issues. But at least some readers will be disconcerted or confused by the book's odd internal tension, and so I want to look at each side of the duality more carefully. I am going to focus first on the (anti-economic) soul of the book. Then I will turn to the other soul, and particularly to the implications of the last chapter's concessions to tradeable pollution rights. Finally, I will go back to the first and dominant soul, to try to locate the source of the author's general dyspepsia about economics, because I think his own book suggests some more charitable ways to think about the devilish dismal science in the environmental context.

\section{Number ONe SOUL ATtempts to CAST OUT ECONOMIC DEVILS}

Sagoff's book sets up a number of oppositions or contrasts that will be familiar to readers of his earlier articles. It is not hard to see that in these oppositions, Sagoff wants to preserve the high ground for his own "ethical" point of view. Here are the big ones:

Ethics vs. Economics (pp. 80, 92, 196)

[Public] Values vs. [Private] Preferences (pp. 9, 90)

Citizen vs. Consumer (pp. 7, 27, 53)

Deliberation vs. Dogmatism (pp. 12, 77)

Environmental issues, he says, have to do with the left-hand side - ethics, values, citizens, and deliberation - and not with economics, preferences, consumerism, or dogmatic pseudoscience. Now, can you guess which side wears the white robes, and which side has the horns and tail? If you don't get the message, you might try one of the author's narrative versions of the oppositions: for example, the contrast between a "majestic million-year-old wilderness" on the one hand, and "Disney playland[s]" and "commercial honky-tonk[s]" on the other. ${ }^{4}$

3. For a recent discussion of the merits of such schemes, see Ackerman \& Stewart, $R e$ forming Environmental Law, 37 STAN. L. REV. 1333, 1341-51, 1360-64 (1985), and authorities cited therein (particularly at 1337 n.11) (response to Latin, Ideal Versus Real Regulatory Efficiency: Implementation of Uniform Standards and "Fine-Tuning" Regulatory Reforms, 37 STAN. L. REV. 1267 (1985)).

4. Pp. 52, 59-60. Some, including my colleague Mark Grady, who professes to have visited the Magic Kingdom well over 200 times, may take offense at the implicit disparagement of Disney enterprises. I myself take offense at the totally misguided disparagement of honky-tonks. To the connoisseur, the honky-tonk represents a charming mix of pedal steel guitars, wailin' tunes, longneck beer bottles, and the Texas two-step, as in Hank Williams' classic lines, "If you got the money, Honey/ I got the Ti-i-i-me/ We'll go honky-tonkin' and we'll have a time." Moreover, the word draws out subtle arguments about gender roles, as in the controversy begun in Hank 
So just how high is this high ground that Sagoff is appropriating for his left-hand side of the column? The best way to find out is to think through the oppositions.

\section{A. Ethics ys. Economics}

After reading this book, I still don't quite know what this ethics stuff is for Sagoff, or why he plays ethics off against economics. In fact, Sagoff himself doesn't give the reader many clues about what he is calling "ethical" until well into the book, when he starts to tell us something about the "normative position" (p. 90). But it's still not so clear; here and elsewhere he gives Kant pretty big play, ${ }^{5}$ and it seems that by "ethics" he means something like Kantian categorical imperatives, and that "ethics" have to do with actions that are right in themselves. Some of the time it sounds as if he doesn't include consequentialism in the category of ethical thinking at all, ${ }^{6}$ but then again, he sometimes seems to approve of talk about the "good" as well as the "right" (pp. 94, 155-58). It's all a bit murky.

Either way - whether "ethics" is about the right thing to do, or about the good life - one might well ask: Why should either view be opposed to economics? If you take the economists at their word, they are quite happy to have you approach issues in either of those ways, or in some other way if you like. They don't care if you want to do the right thing, or alternatively, if you want to do the thing that will lead to good results. They just want to know what everybody thinks are the right things to do (or, if it's allowed, what everybody thinks are

Thompson's The Wild Side of Life ("I didn't know God made honky-tonk angels/ I might have known you'd never make a wife") (Capital 1952), and responded to by Kitty Wells, It Wasn't God Who Made Honky-tonk Angels (Decca 1952) (my emphasis). My thanks to Ronnie Pugh of the Country Music Hall of Fame and Museum in Nashville for assistance on this point.

\section{E.g., pp. $44,155-56$.}

6. For example, when Sagoff describes environmentalists as taking a "moral" position about the environment, p. 154, which apparently precludes consideration of welfare-enhancement, he has already contrasted his "moral" position to utilitarianism. P. 152. This would suggest that he does not think utilitarianism or consequentialism is "ethical" or "moral." The same view seems to be behind a rather odd argument he makes against the welfare economists' goal of efficiency. He argues that this position is not really consequentialist or utilitarian at all, since it considers expected utility rather than actual consequences. Pp. 104-07. He cites the case of poor Romeo's purchase of poison, and his mistaken expectation of relative happiness from the transaction, to show how actual consequences diverge from expected ones. P. 105. An economist, of course, might point out that Romeo's real problem was an insufficient market for information, but I will put that to one side. What is odd about the argument is that any consequentialist ethic is based on guesses about the future (i.e, expected outcomes), and of course runs the risk of mistakes about actual outcomes. Indeed, Sagoff is repeating one of Kant's critiques of consequentialism generally - that human beings' will is not directed at appropriate consequences in advance, and that one does not know how one's supposedly utility-maximizing behavior will come out in fact. See I. Kant, Fundamental PRInciples of THe Metaphysic of Morals 27, 47-48 (T. Abbott trans. 1987) (people make mistakes about outcomes, can't know what will make them happy and thus can't act on definite principles to achieve that end). If one rejects efficiency because it is oriented to expected gains, one also rejects consequentialism generally - again suggesting that Sagoff rejects consequentialism as an ethical position. 
good results). After they get an answer to those questions, economists want to take a further step, to try to get the most of whatever it is that people think is right (or good). ${ }^{7}$

So clean air is what you think is right, or good? Great, says the economist. Now, how good or right do you think it is? Do you think having electricity is right too (perhaps because it's right to have light, heat, and dialysis machines)? You do? That's great too. Now, electricity generation usually messes up some clean air, and this is where the economists think they can be helpful: They think they can help you to decide between two right actions if you can't do both, or, at least, if you can't do all you want of both.

On this issue, they think, you're not going to get anyplace by saying that clean air and electricity are both good, or right, or really, really, really right or good. When you can't have all you would like of both, all that stuff is just palaver. You've got to ask the questions the economists ask: Which course do you think is better, and at what levels? How much clean air is better than how much electricity? That's what economists are trying to find out when they ask those annoying questions about how much you would pay for environmental goods, or values, or whatever. They aren't telling you what to value, but are trying to find out what you do value, and how much, by comparison to other things you value.

Sagoff makes a big deal of the way people get mad sometimes when economists ask them those weird questions about how much they would pay for environmental goods like clean air and wilderness (pp. 83-84). He takes these reactions as a signal that economists aren't thinking about the environment as citizens would, that is, in an ethical way. But what's the big surprise if people get mad at those kinds of questions? None of us likes the news that the preservation of one resource may come at the cost of something else. We dislike that news most of all when we were thinking that at least some of our favorite resources were free. But then, that's why we have environmental problems, isn't it? Here we were, humming along with the happy thought that the best things in life are free, and using up air and wilderness with the reckless abandon we reserve for "free" goods. Now, along comes some squinty-eyed economist with a lot of questions about how much we would pay for those things. No wonder everybody wants to shoot the messenger. Pay? For air? For the great outdoors? Who is this bozo?

7. See Meyers, An Introduction to Environmental Thought: Some Sources and Some Criticisms, SO IND. L.J. 426, 450-52 (1975). Sagoff (e.g., at 43, 45-46) thinks that this kind of neutrality neglects the difference between political values and personal preferences. See, e.g., pp. 43, 45 46; see also infra text accompanying note 33. But Dan Farber, who rejects Sagoff's values/ preferences dichotomy, points out that noneconomists may be persuaded on grounds of political theory to share the economists' neutrality on values. Farber, From Plastic Trees to Arrow's Theorem, 1986 U. ILL. L. REV. 337, 350-51. 
He's the successor to Adam Smith, that's who. And before you do shoot the messenger, just remember, he doesn't have anything against Immanuel Kant, whatever Sagoff might think; he just wants to know how the Kantian aspirations come out when they conflict at the margin, in this vale of tears called scarce resources. Remember, when the economist asks those creepy questions about paying, he's not trying to tell you what you should or shouldn't value; he's just asking what you do value, and how much, so that he can help you figure out how to get the most of what you do value, when your values can't all be satisfied at once. ${ }^{8}$ What's the matter with that? Surely you don't want to have or do less of whatever things your ethics tell you are the right things to have and do.

So Sagoff's opposition, Ethics vs. Economics, doesn't look all that convincing as an opposition after all. Through the book, Sagoff drops a few hints that he may not quite believe in it himself, 9 and by the last chapter, he seems to tank it altogether. ${ }^{10}$ How about the other oppositions?

\section{B. Values vs. Preferences; Citizen vs. Consumer}

These two oppositions are so closely intertwined that I have to deal with them together. Early in the book, one notices that Sagoff rails at economists for failing to take environmental "values" into account, and then he turns around and rails at them even more when they try to do just that. ${ }^{11}$ The poor economists: First everybody said they ignored nonmarket goods, like wildlife and mountainous scenery; and now here is Sagoff telling them they are imbeciles and rogues for trying to translate those nonmarket goods into a cost-benefit calculation for decisionmakers. What's going on here?

What's going on, Sagoff says, is that economists want to talk about environmental matters as if they were (private) "preferences," when they really are (public) "values" (p. 93). When people talk about the environment, he says, they aren't talking about what they prefer for private consumption; they are talking, as citizens, about the things that have value for the whole community (p. 94). So you can't just do a cost-benefit analysis of environmental values, as if you were adding

8. Note that the tradeoffs are not just between, say, industry and clean air, but also among industry-with-some-coal-scrubbers, sort-of-clean air, and a lot of other things we want. You can have some industry, and some clean air, if you pay for the scrubbers, and you can have even cleaner air if you pay for more scrubbers, but the scrubbers themselves aren't costless. They. divert resources, talent, and worktime that might have contributed to other activities, such as constructing violins or finding a vaccine for AIDS.

9. See, e.g., pp. 71-72 (perfect environmental purity may give way to other considerations); p. 80 ("We must acknowledge, however idealistic we may be, that clean air, workplace safety, and the like have a price .....").

10. Pp. 195-224. See infra text at notes 26-28.

11. E.g., pp. 9-10, 27, 35-39, 90-91. 
up what people say they would pay for a pastrami sandwich. With the environment, they are talking about what is valuable for the community as a whole, not their private preferences.

Now, get ready, because here comes the clincher: Mixing up these discourses, Sagoff says, is a "category mistake" (p. 92). "Category mistake"? My Irish grandfather, who sold liquor, would have said, 'Darlin', when they say somethin' fancy like that, close the cash register." But I will take the risk of leaving the register open for the time being, and take up the point.

The point is, I don't know where this alleged category mistake happens. Or if there is some mistake, it is a mistake that is thoroughly embedded in ordinary discourse; and this makes it a little harder to see as a mistake in the first place, at least for somebody like Sagoff, who professes to reject dogmatic versions of knowledge in favor of Richard Rorty's kibbitzing approach. ${ }^{12}$

Let me unpack this:

(i) Just for starters, why does Sagoff seem to think that public values are a matter of discussion, while private preferences aren't, and are just hanging there like lurking components of an idiot id? Surely preferences - including consumer preferences - are educable. ${ }^{13}$ Once educated, we may start to call preferences "tastes," but the point remains: One can educate one's preference for movies, beer, music, and all the rest. Moreover, people routinely do so through discussion with other people.

For argument's sake, let's go along with Sagoff's view that one's liking for ski areas is a private or consumer "preference," as opposed to the public "value" in one's yen for wilderness (p. 52). Surely people can educate their liking for either ski areas or wildernesses, and surely they can learn to like one more than the other. It hardly seems a "category mistake" to see both consumer preferences and so-called public values as learned, and educable, desiderata.

(ii) More generally, why does he think there is some qualitative difference between public values and private preferences? People mix up private and civic concerns all the time, and put them all in the same hopper. Sagoff's students, who valiantly chose wilderness despite their fondness for ski resorts (pp. 52, 70-73), may well have wanted both wilderness and ski areas, but they may just have wanted wilderness more, and chose wilderness when they knew they couldn't have

12. Pp. 12, 222. See also text at notes 22-25. Rorty himself describes his approach to knowledge as "conversation," and also uses the phrase "useful kibitzing." See R. RORTY, PhILosoPHY AND THE MIRRoR OF NATURE 391, 393 (1979) (rejecting epistemological notions of mirroring truth, in favor of more open-ended conversation).

13. Sagoff does acknowledge that private tastes may be educable, p. 104, but most of his discussion sharply distinguishes individual values on public matters, which are shared and discussed with others, from the personal preferences that seem to be undiscussed and amoral. See, e.g., pp. 55, 100, 104. 
both in one place. ${ }^{14}$ But they are still considering the two not as qualitatively separate categories, but as alternative good things.

It is no big secret that people think and talk about a lot of public and private matters as alternative goods. Take for example a citizen's reaction to a proposal for a new sidewalk assessment. She thinks, in rapid succession: (1) Gee, a new sidewalk would look great in front of the house; and (2) it would make the whole block look spiffier, and give the neighborhood a boost; but (3) it does sound kind of expensive for my budget; and (4) it is really going to take a bite out of old Mrs. Jones' pension.

This is an entirely normal progression of thinking about civic decisions. Does anyone except Sagoff really think that there is some sharp divider between the "public" and the "private" aspects of these reflections, or that some of these aspects are inappropriate to the citizenry's deliberations on matters of public importance? ${ }^{15}$

(iii) To illustrate the supposed category mistake in mixing preferences with values, Sagoff occasionally poses a cute hypothetical: Someone who is promoting a particular public policy is asked how much he would pay to have his policy put into place (pp. 9-10, 223). The very question is supposed to illustrate that it is ridiculous to mix preference-talk with value-talk.

Well, one can agree that this would normally be an odd sort of question, but one still wouldn't have to concede that there is some absurdity in policymakers' consideration of preferences. For one thing, sad to say, sometimes policymakers are thinking about how much they would pay, or to put it on the other side of the Coase theorem, how much they are getting paid for taking particular public policy positions. That is to say, they are thinking about their own consumer preferences when they support certain public policies, because someone is going to pay them for supporting those public policies. ${ }^{16}$

Naturally, we think this is wrong. But it isn't wrong because the legislators are thinking about preferences as such. It is wrong because they are thinking about the wrong people's preferences - they are sup-

14. Or maybe in this class, they thought they would be well advised to want wilderness more.

15. For another critique of Sagoff's division of personal and civic values, see Farber, supra note 7, at 344, 347. Cass Sunstein, some of whose work Sagoff approvingly cites, pp. 10-11, does distinguish public and private spheres but does not qualitatively distinguish private preferences from civic values; he rather speaks of levels of preferences, noting that we may have preferences about preferences: we wish we didn't like to smoke, we wish we were more inclined to wear seat belts, etc. See Sunstein, Legal Interference with Private Preferences, 53 U. CHI. L. REV. 1129, 1140 (1986).

16. According to some law-and-economics commentators, that seems to be all that legislators are thinking about, whether they decide for or against legislation. See McChesney, Rent Extraction and Rent Creation in the Economic Theory of Regulation, 16 J. LEG. STUD. 101, 102-03 (1987) (politicians seek to maximize their own returns by forbearing from regulation costly to others). 
posed to be thinking about their constituents' preferences and not their own. As Susan Rose-Ackerman has argued, the legislator who accepts a bribe violates an agency relationship with his constituents, because he is supposed to be thinking about the constituents' preferences, and instead he is thinking about his own. ${ }^{17}$ But the legislator still should be thinking about preferences - that is, those of his constituents. If he isn't, he may not be in office too long, because those constituents are certainly considering consumer preferences when they think about, say, whether they want a bond issue to fund the public schools, or whether they want to clean up the roadsides at the expense of paying a bottle deposit, and how they want their representative to vote on those matters. ${ }^{18}$ This is not to say that private consumption preferences are the only thing that citizens (or their representatives) think about with respect to public affairs, but it is one of the things they think about. What we really may want from our political leaders is some education of our preferences in matters relating to public affairs; after all, they are in office, and are supposed to have the time to think about these things and explain them to the rest of us working stiffs. But citizens and policymakers don't take a vacation from preferences and utility maximization just because they are talking about public issues.

So where's the category mistake in mixing up citizens' values and consumers' preferences? I think I've lost it. Moreover, I think most people never dreamed of it. Ordinary language mixes these up, and treats all of them as appropriate grist in the political "deliberation" or "conversation"19 about public decisions, whether they be environmental or something else.

Despite all this, Sagoff is clearly right that there probably is one important sense in which community goals may diverge from the sum of individual preferences. Take public health, for example: Individual health has repercussions beyond the healthy individual, not only because the healthy person doesn't infect others, but also because she holds a job, plays on the neighborhood softball team, acts cheerful, and in general passes on some nice positive externalities to others. But because some of these good things are externalities, she might be

17. S. Rose-Ackerman, Corruption: A Study in Political Economy (1978). See also Banfield, Corruption as a Feature of Governmental Organization, 18 J. L. \& EcoN. 587 (1975). Sagoff professes to have some experience with bribes, p. 52, and might object that bribing a judge is different, because a judge is not supposed to be thinking about constituent preferences. But a judge should be thinking about constituents' "preferences about preferences," as these are incorporated into the rules of behavior that constituents have given themselves. See Sunstein, supra note 15.

18. When Sagoff suggests that costs are unimportant by saying, for example, that maintenance of the national parks in the face of economic progress is an ethical, and not an economic, issue, he may be understating the significance of cost considerations in political decisions. See, eg., Girdner, Timber War Pits Law Students vs. Loggers, Boston Globe, Oct. 24, 1988, at 53, col. 3 (describing local opposition to student efforts to preserve old-growth forests).

12.

19. "Conversation" is from Richard Rorty, whom Sagoff cites approvingly. See supra note 
tempted to scrimp on expenditures for her own health. And the same goes for everyone else in the community: taken in the aggregate, individuals might not put enough resources into things that are beneficial not just to themselves, but to everybody else too. But the community as a whole will be better off with a higher level of expenditure. The more general point is that the community as a whole has objectives that may differ from the sum of individual wishes; perhaps this was what Rousseau had in mind with all the pluses and minuses in the "general will."20 On these matters, we want citizens and legislators to pay attention to common goods and evils, which do diverge from aggregated individual preferences.

This is not news in the literature from economics and economicsinfluenced branches of political science. On the contrary, there is a whole body of work out there about public goods and positive sum cooperative "games," and though not all of it is written by creepy neoclassical economists, economists have certainly had some influence on the discussion. ${ }^{21}$. It is a pity that Sagoff does not seem to have addressed this work, for two reasons. First, some of this literature offers some reasons for the public preservation of the environmental goods that Sagoff rightly thinks are so important. And second, this literature poses very important political questions about how people might get over the impulses they have to act self-interestedly, under circumstances where narrow self-interest is inappropriate, and why they might cooperate instead for a greater common good - questions that seem to me to be central to Sagoff's interest in public values. I will come back to this later.

\section{Deliberation vs. Dogma}

I am not going to say much about this opposition here. It's now quite trendy to describe one's opponents as snapping their chops over dogmatic scientism, while describing oneself as engaging in deliberation or conversation, where the participants are civil and openminded. ${ }^{22}$ No doubt deliberation is a good thing. But here it looks a

20. William Ophuls, in the context of his discussion of the "tragedy of the commons," notes the relationship between Rousseau's "general will" and the divergence between community good and additive individual preferences. W. OPHULS, ECOLOGY AND THE POLITICS OF SCARCITY: Prologue to a Political Theory of The Steady State 150-51 (1977). Sagoff also mentions Rousseau, although he does not give the same reasons for the difference between individual and common goals. P. 11.

21. See, e.g., R. Dorfman, Measuring BeneftTs of Government INVESTMENTs 4-5 (1965); R. HARDIN, COLlective Action (1982); Hirschleifer, Evolutionary Models in Economics and Law: Cooperation versus Conflict Strategies, 4 RES. L. \& EcoN. 1 (1982); Schelling, Hockey Helmets, Daylight Saving, and Other Binary Choices, in Micromotrves AND MACROBEHAVIOR 211 (1978).

22. For a witty example, see "D.A.F." [D. Farber], The Zapp Complex, 5 ConsT. CoMmENTARY 13, 14-16 (1988) (complains about law review articles' excessive length and footnotes as attempts to have last word instead of engaging in "conversation" a la Richard Rorty). 
little like a trick, because the reader never does get much of a sense of what the deliberation is supposed to be about. In fact, it looks as if the deliberation isn't supposed to be about anything in particular. ${ }^{23}$ Dressing up a nonposition as "deliberation" seems like thin stuff, and not much more than another effort to lay claim to the high ground sort of like opposing gorgeous scenery to honkytonks. Yeah, yeah, maybe the economics crowd does tout itself as predictive scientists, ${ }^{24}$ but it doesn't sound very civil and open-minded to say they are just making "category mistakes" either - in fact, the very phrase sounds like the kind of Intimidator Ray Gun that philosophers whip out to shut up everybody else. ${ }^{25}$ Now, I do think there is more to Sagoff's claim to "deliberation" than just posturing, and I'll come back to it, but I don't think Sagoff has spelled it out well enough to do justice to his own position vis-à-vis those economic devils.

Maybe that's why they get him by the end of the book.

\section{Number Two Soul Gives IN to Tradeable EMISSION RIGHTS}

A kind of diabolical conversion occurs in the last chapter of this book, where Sagoff puts in a plug for tradeable emission rights those inventions of economic environmentalists. ${ }^{26}$ The tradeable emission right idea (which I will call TER) is now a familiar one. In this scheme, we start by setting overall ambient limits for any given pollutant, first by guessing about our health-based and aesthetic tolerance to the pollutant, and then by weighing those factors against our need for products that require the pollutant, and other costs incurred in restraining it. After we have made these calculations and set upper limits, would-be polluters can get permits to pollute, but they have to bid and trade for these now-scarce entitlements. This makes polluters more cost-conscious and more likely to find ways to cut back on their pollution, but we leave it to them to figure out the most cost-effective ways to do so; this is presumably cheaper and more flexible than would be our own efforts to try to figure out controls for them.

In my view, Sagoff's chapter bringing up this approach is among the most sensible and interesting parts of his book, because it is the one place where he starts to reckon with the problem of scarce resources, and with the difficulties of allocating and restraining uses of

23. E.g., pp. $215-16$.

24. See White, Thinking About Our Language, 96 YALE L.J. 1960, 1967-68 (1987) (economists, as example of "conceptual" thinking, may see role as putting forth verifiable hypotheses in manner of science).

25. Not that economists are easy to shut up - they've got some ray guns of their own, like "cross-elasticity." What could be more of a silencer than that? - maybe the lit-crit crowd's phronesis, or trope, or aporia. For a comment on "fancy scholarship" in the law, see Schlag, Comment: The Brilliant, the Curious, and the Wrong, 39 STAN. L. REv. 917 (1987).

26. See supra note 3. 
resources that are normally seen as "commons." But I think his endorsement of the TER idea creates some problems for his position about environmental values, and that TER really undermines the whole set of oppositions that inform the bulk of the book. The basic problem is that the structure of tradeable emission rights serves up values and ethics right along with mere low-life consumer preferences. In a TER regime, everything is on the menu, and everything gets traded off with everything else.

Sagoff likes TER, because he says that one can base the overall pollution standards on ethical considerations, like health and aesthetics (pp. 210, 213). And indeed one can. But as he seems to realize (pp. 197-98), nobody has to do this - there is nothing in the TER concept that privileges "ethical" environmental concerns over "consumer" concerns about, say, the cost of pollution controls. ${ }^{27}$ What does this mean? It means that on the level of setting the overarching pollution limits, my private "preference" for keeping my dollars in my pocket gets into the same discussion with Sagoff's high ethical "value" for spending my consumer dollars to clean up duckponds in Arkansas. Is his ethical choice going to trump my personal preference? Nope. He may win or he may lose, but in principle, under a TER regime, the setting of overall pollution levels need not give his environmental ethics any special place. Instead, a TER regime tries to figure out how much his ethical values are worth, vis-à-vis my low-life preference for cash.

There's another way that TER-thinking messes up the purported opposition between values and preferences. Let's suppose that ethical values do have some privileged position at the policy level - that is, let's suppose they do count a bunch when we are setting overall standards, in the sense that we damn the costs in order to get, say, healthful air. Parenthetically, I agree with Sagoff that a lot of legislation does this, though perhaps not so much as he suggests. ${ }^{28}$ But even sup-

27. Indeed, costs - especially the costs of "do-your-best," technology-based pollution control devices - have been one of the major impulses for turning to TER-type approaches. See Ackerman \& Stewart, supra note 3, at 1338-40; Note, Technology-Based Emission and Effluent Standards and the Achievement of Ambient Environmental Objectives, 91 YALE L.J. 792 (1982) (criticizing performance standards as costlier and less beneficial than pollution-rights approaches); see also Krier \& Montgomery, Resource Allocation, Information Cost and the Form of Government Intervention, 13 NAT. RESOURCES J. 89, 99-101 (1973) (suggesting that interest in pollution pricing/trading schemes stems from lower costs of those schemes). TER schemes do have their critics; see Latin, supra note 3 (arguing that pollution entitlement schemes are practically unmanageable and undermine more feasible environmental control efforts based on technology). Costs, of course, may be seen either as flat cash, or (in more sophisticated versions) as the diversion of resources and related lost consumption opportunities.

28. Sagoff often refers to sections of environmental or health statutes in which the legislatures or the courts have stated that costs will not be counted, to suggest that costs are seldom or never considered in environmental laws. See, e.g., pp. 36 (discussing Clean Air Act, Endangered Species Act), p. 84 (discussing Clean Air Act, OSHA), p. 197 (discussing several statutes). This gives a misleading impression. There are a number of statutory sections where costs are specifcally mentioned. To give one example, $\S 111$ of the Clean Air Act, dealing with uniform federal 
posing that "values" rule at the standard-setting level, TER still takes the economists' position of agnosticism about values at a lower level. This means that if Sagoff and I both get a small allocation of the few tradeable pollution rights that are allowed, he can hoard his (to protect the air, which he values so highly). I will be delighted, because he is limiting an already-scarce supply even more, and making my pollution rights even more marketable. Because of his noble self-sacrifice, I can get an extra bundle when I sell my now-even-scarcer pollution rights to the styrofoam cup makers. Shoot, maybe I can get enough to finance a trip to Disneyland, and surely enough to go honkytonk-hopping. What do I say to Immanuel Kant's categorical imperative? Hey, take gas, Manny Baby.

The point is that if I can act this way under a TER regime, then the TER regime swallows up Sagoff's ethical and public values in the great maw of economic devilry. What's notable about the book is that by the end, Sagoff seems to have fallen at least as far as the First Circle.

\section{REDEMPTION THROUGH RHETORIC}

So what is ailing our Faust, anyway? Why does he burn so hotly about economics, when he concedes so much? I think that what's getting to Sagoff is the rhetoric of economic discussion, not its category mistakes.

Sagoff does not say this in so many words, but he implies that one aspect of economic rhetoric is me-first-ism. ${ }^{29}$ For all the supposed indifference to goals in economics, preference-talk has the sound of an irreducible egotism, and implies that preference bearers, in their end-

controls on stationary pollution sources, requires the Administrator to set performance standards based on the best available technological controls for emission reductions, "taking into consideration the cost of achieving such emission reduction," as well as other health, environmental and energy considerations. 42 U.S.C. $\$ 7411(a)(1)(C)(1982)$. Sagoff himself notes in passing the cost considerations in this and other sections, p. 201, but only in his last-chapter conversion to taking costs seriously. And even there, when he directly quotes this section, he omits its reference to costs. Pp. 201, 207-08, 211. But cost considerations do come into play repeatedly in this and other areas of environmental law, despite grand statutory prefaces about eradication of pollution; the Clean Water Act, for example, makes a number of concessions to cost considerations, such as the provisions that permit the states to determine varying levels of water cleanliness for varying purposes, including agricultural and industrial purposes. See Clean Water Act, § 303(c)(2), 33 U.S.C. $\$ 1313$ (c)(2) (1982). The "Superfund" statute provides for a National Contingency Plan to set priorities for responses to hazardous substance releases, and requires that relative magnitudes of danger be taken into account as well as costs of remedies. Comprehensive Environmental Response, Compensation and Liability Act, $\S 105,42$ U.S.C. $\S 9605$ (1982 \& Supp. IV 1986). As noted above, the recent interest in emission-rights approaches is closely related to concerns that environmental regulation may be costlier than necessary. See supra note 27. For some observations on the relation of control costs to environmental benefits in environmental law, see Stewart, The Role of the Courts in Risk Management, 16 ENVTL. L. REP. (Envtl. L. Inst.) 10,208 (1986) (discussing a "risk portfolio" approach).

29. See, e.g., pp. 55-56 (suggesting that economists disregard or attempt to paper over nonself-regarding choices). 
less pulse-checking for their own preferences, really don't give two hoots about what their neighbors might want or need. Now, maybe this is a mistaken notion of what economists think, but mistaken or not, the rhetoric matters: If all this preference-talk gives you the idea that you are alone in caring about the neighbors, you may be less willing to act in their behalf. Why be the sucker when the rest of them are all out for themselves? ${ }^{30}$ That sort of attitude, of course, leads everybody down the primrose path to the old Prisoner's Dilemma, the ultimate noncooperative end to what should be a cooperative game, the point where me-first-ism impoverishes all the players. ${ }^{31}$

Environmental problems are often commons problems, and thus they present just such Prisoner's Dilemma "games";32 and insofar as this is true, as I mentioned earlier, the big task is to induce people to cooperate for the common good. In that task, it doesn't always help to have a very powerful rhetoric suggesting that charity and fellow-feeling, while just as good as any other preferences, are really not to be expected - so get yours while you can.

That is one rhetorical aspect of economic talk that may be getting under Sagoff's skin. I am less tentative about saying that he is bothered by a second rhetorical aspect: that is, the purported economic agnosticism about goals, which suggests that goals are all alike and that there is not really much point in talking about them. ${ }^{33}$ So you like wilderness? says our economic poll-taker. Great - but let's not talk about why. Sagoff, on the other hand, wants to say that you can talk about these matters, and that there is something you can say to shape goals. ${ }^{34}$

On this point, although I disagree with Sagoff's sharp opposition between preferences and values, I think he is on to something. People do talk about the things they want; they change their minds as a result of discussion; they have informed views on what is desirable and why; they talk about traditions and practicalities - and this discussion puts them into a kind of fellowship with other participants in it, including those with whom they disagree on any particular issue. In this sense, Sagoff is not just being trendy in his appeal to Rorty and "deliberation" or "persuasion."35 When I want to sell my pollution rights to

30. On a related point, see Radin, Market-Inalienability, 100 HARv. L. REv. 1849, 1877-87 (1987) (rhetoric of commodification may distort perceptions and attitudes about relationships among people).

31. For this much-discussed "game," see R. HARDIN, supra note 21, at 24; Hirshleifer, supra note 21 , at $13-14$.

32. See W. OpHuLs, supra note 20 , at $145-47$.

33. Sagoff focuses on this point at pp. $45-46$ (cost-benefit analysis indifferent to values) and pp. 40-41, 80-81 (economists treat goals as "exogenous," to be toted up by "appropriate software").

34. E.g., p. 120.

35. See supra text accompanying notes $22-25$. 
the plastics factory, maybe Sagoff and I can talk it over, and maybe he can talk me out of it.

But how is he going to do that? The book is more than a bit frustrating on the things that go into our deliberation: What do we deliberate about, and especially, what kinds of topics will withstand the economic rhetoric that suggests we won't really deliberate at all? Sagoff's major way around this rhetoric is the appeal to "ethics" and to all those other things on the left-hand side of the list of oppositions. As I have said, I don't think these oppositions stand up very well. So what other routes are there to redeem our Faust and get him out of economic hell? What other counter-rhetorics might get around the rhetoric of Me-First and No-Discussion?

One route Sagoff touches upon is the somewhat amorphous work that has been classed as "deep ecology" - a set of writings characterized by their urging that we acknowledge a kind of feeling-in and feeling-with nature. ${ }^{36}$ This is not preference-talk, but kinship-talk. Sagoff's interesting chapter on the history of environmentalism brings up this way of talking, pointing out the symbolic impact of nature in our cultural history. 37

It takes a lot of nerve to get into a discussion of kinship with nature, as the ideas can be easily pooh-poohed; ${ }^{38}$ besides, it is not altogether clear that the concept - or feel - of deep ecology can be conveyed adequately by argumentative discourse at all. As Sagoff suggests in his discussion of American literature, ${ }^{39}$ this kind of insight may only come through experience, or through artistic and narrative renditions of experience - which may be the reason why people like the photographer Ansel Adams and the storyteller Edward Abbey are so important in environmental history. ${ }^{40}$ Sagoff's discussion of an aesthetic or a narrative counter-rhetoric is an important contribution to the environmental "discussion" - and in my view considerably more provocative than his preferred argumentative rhetoric of "ethics."

A second route or counter-rhetoric is an expanded version of rights. Sagoff mentions this route in his nods to libertarianism on the one hand (p. 16) and to animal-rights advocates on the other (pp. 15657). Rights-talk is tricky, though, because rights and entitlements are very much a part of the neoclassical economic baggage: Fixed and firm entitlements, one might think, are only there in order to assist in

\footnotetext{
36. For a discussion of the various sources of this literature, see Devall, The Deep Ecology Movement, 20 NAT. Resources J. 299 (1980). See especially id. at 309 (deep ecology tries to avoid focusing on human needs, instead tries "thinking like a mountain").

37. See ch. 6, "Nature and the National Idea," pp. 124-45, particularly pp. 141-44.

38. See, e.g., W. BaXter, People or Penguins: The Case for Optimal Pollution 5-9 (1974) (rejects idea that nature has normative content aside from human preferences).

39. E.g., pp. 142-43.

40. See Devall, supra note 36, at 308; R. NASH, WILDERNESS AND THE AMERICAN MIND 263-65 (3d ed. 1982).
} 
investment, trade, and all those Pareto-optimal moves in the Me-First universe. ${ }^{41}$ Maybe this explains why Sagoff himself is leery of rightstalk. ${ }^{42}$

But rights-talk has another rhetorical face as well. As Martha Minow has pointed out, by applying rights-talk to such unexpected subjects as children and the mentally disabled, one invites the listener to take seriously their condition. ${ }^{43}$ These unorthodox subjects are not at all the usual rights-bearers, who defend their own entitlements. But the very metaphoric quality of rights-rhetoric, on behalf of those who are somehow rights-disabled, bridges a gap to the more ordinary rights-holder, and adds drama to the plea to consider their situation, as if they could stand up for rights in a more conventional way. Thus rights-talk may borrow the neoclassical rhetoric of entitlement, but may turn that rhetoric around to lend gravity to the discussion of novel subjects. Minow uses this rhetorical turn for children, but one could do the same for animals and plants and places of breathtaking beauty.

The turn-around in the rhetoric of rights suggests still another kind of counter-rhetoric, one that Sagoff eschews, though I think perhaps too hastily. It is the counter-rhetoric of cost-benefit analysis, which seems to me to have done a good deal to get us off the mark in thinking about the desirable qualities of the natural environment. Sagoff feels a monumental fury about the "shadow-pricing" of environmental benefits (pp. 88-92). He is right in a way; it does seem jarring to cost out, say, the scenery at Mt. Whitney.

But why shouldn't we see that shock as the same kind of shock that comes with the discussion of trees having rights? ${ }^{44}$ Why not see it as an effort to bridge a gap, to dramatize the value of things that are too easily ignored, to invite a discussion of the things we value, even though the neoclassical market rhetoric seems deaf and dumb about them? So what if we borrow that market language? We have to use what we have, and this talk may help to disarm those who would simply ignore environmental values. More important, the very pirating of

41. See Rose, Crystals and Mud in Property Law, 40 STAN. L. Rev. 577, 577-78, 605-06 (1988); see also Tushnet, An Essay on Rights, 62 TEXAs L. REv. 1363, 1392-94 (1984) (rights-talk is a part of capitalist culture and focuses on negative rights of individuals rather than positive claims of those in need); (f. Perry, Taking Neither Rights-Talk nor the "Critique of Rights" Too Seriously, 62 TEXAS L. REv. 1405, 1415 (1984) (Tushnet offers no better alternative to rights rhetoric to support claims of needy).

42. Sagoff, however, says that he rejects rights-talk in environmental law because the rights concept is either inconsistent or overly rigid. See pp. 156-57.

43. See Minow, Interpreting Rights: An Essay for Robert Cover, 96 YALE L.J. 1860, 1866-67, 1892-93, 1907-08, 1910-11 (1987) (second meaning of rhetoric of rights, inviting "conversation" about unconventional claims).

44. See C. Stone, Should Trees Have Standing? Toward Legal Rights for NatuRAL OBJECTS (1974). For Stone's most recent effort, see C. STONE, EARTH AND OTHER ETHICS: The Case for Moral Pluralism (1987), which again focuses on the moral status of nonhuman things. 
market-talk adds to its metaphoric power when we use that talk to dramatize things that are not bought and sold at all. It's a dangerous game, to be sure, but the imaginative use of rhetoric may open up some minds that would otherwise be closed.

The major problem of environmentalism is that we live in an imperfect world of limited resources: There just isn't enough of everything to have all we would like, or even all we think would be good for us. But in talking about the environment, we realize that we live in a limited rhetorical world, too. We can't talk about the natural surroundings as we no doubt romantically dream that the Native Americans did in olden times - with ease, grace, and transparent understanding of the awe and loveliness of the earth and its creatures. Instead, we have all this pinched yakking about what's mine, and what's yours, and how much you are going to have to pay me if you want to get what's mine. But there are ways to build on this rhetoric, ways to move out from under its limitations.

Sagoff's book gropes toward a different rhetoric, and while he concentrates on his sharp distinctions between ethics and economics, I think he makes a much more substantial contribution with his brief discussion of narrative and artistic renderings of the experience of nature. Still, my chief concern is that he is neglecting the rhetorical resources that are available in other standard ways of talking. On the subject of economics in particular, his book sends the very mixed but still rather conventional - signals of sin and salvation. A less belligerent exploration, on the other hand, might have opened up some more creative rhetorical possibilities in the language of rights, entitlements, and even costs and benefits. But whatever the price the book pays to its own Manicheanism, it does make some important contributions, and I have to hand it to Sagoff: What he has done better than anybody else so far is to point out that the way we talk about the environment is going to influence the way we think about it, and the things we do about it. 


\title{
AUTOPOIETIC LAW: THE NEW SCIENCE OF NIKLAS LUHMANN
}

\author{
Arthur J. Jacobson*
}

AUTOPOIETIC LAW: A NeW APPRoach to LAW AND Society. Edited by Günther Teubner. Berlin: Walter de Gruyter. 1988. Pp. viii, 380. $\$ 98$.

The publication of Autopoietic Law: A New Approach to Law and Society, edited by Günther Teubner, ${ }^{1}$ is an event of real intellectual importance. The fifteen essays by legal theorists from throughout the world mark the appearance of a novel paradigm in legal theory - the biological model of autopoiesis. They also make a Festschrift of sorts for Niklas Luhmann, a brilliant expositor of the paradigm. Though the name - and some of the prose - is quite forbidding, common lawyers should be keenly interested in this collection. Autopoiesis, after all, is the first image of law drawn from science that comes even close to revealing the secrets of common law's own harsh discipline.

"Autopoiesis" means "self-production." Biologists and systems theorists use the term to describe a self-referential system - one that "constitutes the elements of which it consists through the elements of which it consists" (p. 14). The core image of autopoiesis is the individual organism, ceaselessly generating elements out of elements, forming each element into an indissoluble unity from a more complex base of energy and matter (p. 14). Every element of an autopoietic system is produced by and produces the operations of the system. All elements are produced means of reproducing the system. Elements that do not join the circular dance of autopoiesis are outside the system, part of its environment. They may affect elements in the system or be affected by them, but play no role in the operations reproducing the system. Autopoiesis is a new way of understanding the independence and autonomy - the operative "closure" - of systems. ${ }^{2}$

Autopoietic law models the legal systems of advanced industrial

* Max Freund Professor of Litigation and Advocacy, Cardozo School of Law, Yeshiva University. B.A. 1969, Harvard College; J.D. 1974, Harvard University; Ph.D. Government 1978, Harvard GSAS. - Ed. Thanks to Drucilla Cornell and Chuck Yablon for their special encouragement. Thanks also to Eric Bregman, David Carlson, Mark Gould, John Leubsdorf, Peninah Petruck, Michel Rosenfeld, and Stewart Sterk for their insightful comments. Dave Trubek opened the door to autopoiesis, for me and many others, in the Conference on Reflexive Law and the Regulatory Crisis, at the University of Wisconsin Law School, July 18-21, 1983.

1. European University Institute, Ser. A, Law 8.

2. P. 15 ("closure consists in the fact that all operations always reproduce the system"). 
democracies as if they were self-reproducing organisms. ${ }^{3}$ The core image of autopoietic law is: (1) a legal system ceaselessly generating (and transforming) legal materials entirely out of legal materials; hence, (2) a legal system continuously setting (and altering) the conditions of its own validity (pp. 17-18). Politics, morality, and many other nonlegal forces certainly affect law in autopoietic legal systems - how could they not? - but they do not determine the validity of legal acts and communications.

Legal theorists have two distinct interests in autopoietic law. The first is the dynamism of autopoietic law, stemming from the first part of the core image. The legal systems of advanced industrial democracies constantly generate and transform law in every legal act and communication. A perpetual motion of norms sharply distinguishes certain legal systems. Autopoiesis is a wonderful image for a system dynamically generating and transforming its own elements. Autopoietic law expresses the essential dynamism of certain modern legal systems more effectively than any prior theory. ${ }^{4}$

The second interest is the unity of autopoietic law, stemming from the second part of the core image. Despite the extraordinary conceptual and practical demands the administrative state has made on them, modern legal systems still claim that legality confers a special brand of validity. ${ }^{5}$ Though deeply affected by the political and moral exigencies of administration, modern legal systems claim that they do not "decompose" to the forces that affect them (pp. 14-15). Though dynamic, modern legal systems still claim to be coherent in the sense that a denizen of the system can at any moment determine the validity of a legal act or statement according to whether it has been produced by operations of the system. ${ }^{6}$ The denizen at all times knows the system's operations and the possible results of those operations. Modern legal systems thus do not abandon the claim to substantive coherence, as

3. Autopoietic law is not meant to be a description of all legal systems. The empirical claim is that autopoietic law serves as an appropriate model for the legal systems of advanced industrial democracies.

4. One of Kelsen's greatest achievements was to be the first legal positivist to model the dynamic character of modern legal systems. See H. KELSEN, The Dynamic Aspect of Law, in PURE THEORY OF LAW 193-278 (1970) (published as the Reine Rechtslehre in 1934).

5. Legal theorists differ sharply on the meaning of "validity." Legal sociologists, such as Luhmann, attempt to clarify the terms of the debate by correlating criteria of validity with specific types of legal systems. That a legal system must use some criterion of validity is probable. Though I shall not explore the subject in depth here, autopoietic law does claim a criterion of validity for autopoietic legal systems - a binary code by which denizens of the system can say whether an act or communication is "legal" or "illegal." See pp. 16, 23-26.

6. Autopoietic law asserts that the criterion of validity need not be stable, or even expressible in rules or maxims available for ready restatement. Nor does autopoietic law require that only one legal act or statement be valid at any single moment. Nonetheless, denizens can at any moment recognize the validity of legal acts and statements, which is all autopoiesis requires. For a compelling criticism of the doctrine of time embedded in this notion of validity, see Cornell, Time, Deconstruction, and the Challenge to Legal Positivism, 1 Yale J.L. \& Humanities (1989) (forthcoming) [hereinafter Cornell, Legal Positivism]. 
legal positivism suggests they must. Yet because modern legal systems are dynamic, no one can point to a single, rationally expressible essence capturing the substantive coherence. Autopoietic law asserts that legal systems can be substantively coherent, despite the lack of a single, rationally expressible essence (p. 21). Autopoiesis proclaims the dynamic substantive coherence - the "unity" - of the legal system in its sustaining control over its own operations (pp. 13-14, 18, 2326). The system is autonomous, because it "can neither derive its operations from its environment nor pass them on to that environment" ( $p$. 18).

My criticism of Niklas Luhmann's construction of autopoietic law ${ }^{7}$ is that he favors the second interest, the operative unity of modern legal systems and their autonomy from the environment, at the expense of the first, the dynamism of these systems. ${ }^{8}$ Luhmann preserves the autonomy of autopoietic legal systems by insisting that they are closed only to legal norms, but open to information from the system's social environment. This formula, normatively closed and cognitively open, draws the teeth of autopoietic law. It makes autopoietic law into fancy positivism coupled with covert naturalism - the static theories of law - rather than an account of law and society that is sensitive to traces of dynamism. While various mixtures of fancy positivism with covert naturalism are endemic in modern legal theory, ${ }^{9}$ they are by no means analytically inevitable or politically desirable.

Two difficulties with Luhmann's formulation drive him to positivism and naturalism. First, autopoiesis itself, as Luhmann is aware, may not be transferable from individual organisms to social systems (p. 14). So long as Luhmann treats the social system as a super-individual, for which autopoiesis is more than an attractive metaphor in the manner of Hobbes' Leviathan, then the key to autopoiesis, the real individual, will be missing. The absence of real individuals leads Luhmann to legal theories that likewise marginalize the individual, namely positivism and naturalism.

Second, assuming it is possible to use autopoiesis to describe the

7. I am deeply aware that autopoietic law, as all real intellectual undertakings, has been an intensely social project. I find it an unfortunate consequence of the limits of energy (and, undoubtedly, the patience of the editors of the Michigan Law Review) that I focus on Luhmann to the virtual exclusion of the other extraordinary contributors to Autopoietic Law. I owe a special apology to Günther Teubner, who has been developing his own brand of autopoietic law, fully as rich and instructive as Luhmann's. See, e.g., Teubner, Substantive and Reflexive Elements in Modern Law, 17 LAw \& Socy. REv. 239 (1983); Teubner, Autopoiesis in Law and Society: A Rejoinder to Blankenburg, 18 LAW \& Socy. REV. 291 (1984).

8. Luhmann's concern with autonomy at the expense of dynamism, while recognizing the prevalence of dynamism in modern legal systems, goes back at least to his 1976 lecture to the Göttingen Rechtswissenschaftliche Gesellschaft. See N. LuHManN, The Autonomy of the Legal System, in The Differentiation of SocietY 122 (1982) [hereinafter N. Luhmann, Differentiation].

9. This is especially true for common law theorists, who cannot compress their tradition within plain positivism or plain naturalism. 
social system as if it were an individual organism, it is difficult to imagine how a subsystem of the social system can itself be autopoietic within the autopoiesis of the entire social system. ${ }^{10}$ The legal system can be autopoietic in its own right only if a subsystem - a discrete social system serving a function within another social system - can be autopoietic. If a subsystem cannot be autopoietic, then the legal system can be autopoietic only as part and parcel of the autopoiesis of the rest of society. The legal system would then be dynamic, but not autonomous. The formula, normatively closed and cognitively open, reflects Luhmann's functional confinement of the legal system within an autopoietic subsystem. The claim that a legal system is an autopoietic subsystem thus stands or falls on Luhmann's ability to distinguish between "normative" and "cognitive." This is an empirical distinction Luhmann cannot validate, though he is correct that the autonomy of the legal system depends on it. ${ }^{11}$ The common law exemplifies the empirical difficulties besetting the distinction. It also puts in question the claim that other legal systems, such as the Continental systems with which Luhmann is undoubtedly more familiar, successfully distinguish between "normative" and "cognitive," and hence are autopoietically autonomous. Failing clear empirical validation of the distinction, Luhmann's formula, and the functional confinement of the legal system it presumes, constitute a normative choice or orientation on Luhmann's part. The normative choice to distinguish between "normative" and "cognitive" leads Luhmann, once again, into a mixture of positivism and naturalism.

Luhmann is not alone in this choice. Modern legal theorists mix positivism and naturalism whenever they wish to confine legal systems within a functionally defined subsystem of the social system. Luhmann works in a theoretical tradition that regards legal systems that are coordinate with the entire social system as "fundamentalist" or "primitive." The common law is coordinate with the entire social system. However, it is neither "fundamentalist" nor "primitive." It supports an advanced industrial democracy.

My criticism thus takes the perspective of a denizen of common law - the legal system of an advanced industrial democracy. Presumably Luhmann is interested in autonomy because he believes that autonomy of the legal system facilitates the development and functioning of advanced industrial democracies. To sustain his claims about autonomy, Luhmann must be able to show that common law systems satisfy his empirical claims about autopoiesis. In particular, the com-

10. Luhmann is also aware of this problem. See p. 19.

11. Luhmann admits that as an empirical matter every operation in law uses normative and cognitive operations simultaneously. He makes fascinating and important theoretical statements about the simultaneity, but the differentiation of the two, given their inevitable empirical coincidence, is surely not capable of empirical validation. See p. 20. 
mon law must vindicate the formula, normatively closed and cognitively open, which expresses Luhmann's analytic emphasis on unity and autonomy at the expense of dynamism.

As Richard Lempert argues in his contribution to the volume, the common law does not empirically validate Luhmann's formula (pp. 178-82). Therefore, the interest of common law theorists in autopoietic law must be the reverse of Luhmann's interest. The common law is vitally concerned with dynamism for its own sake, not as a defensive response to the needs of autonomy and unity. Dynamism, I suggest, is a virtue more hospitable to advanced industrial democracy than are unity and autonomy.

The price of dynamism is undoubtedly a loss of intellectual coherence and perfect autonomy - a rejection of functional confinement. Nevertheless, the key to the common law as a dynamic jurisprudence, which it shares with a whole family of dynamic jurisprudence, is exactly the individualism that autopoiesis attempts to model. ${ }^{12}$ The individual living in a dynamic legal system uses it to draw on the resources of society to perfect his or her individuality, not to mediate between a calculating will and the demands of society. Luhmann's discussion of the motor driving autopoietic law, by contrast, is a story of tautology rescued by utility (pp. 22, 26-28). A common law understanding of autopoietic law - autopoiesis through, rather than over, the heads of real individuals - may ultimately shed light on the general autopoietic account of social systems.

My disagreement with Luhmann centers on the stakes I believe he places on the key theoretical propositions of autopoiesis. For Luhmann, the possibility of an autonomous legal system is at stake, despite the obvious fact that politics and morality infuse legal decisionmaking in advanced industrial democracies. As Luhmann sees it, if autopoiesis is a correct description of legal systems in advanced industrial democracies, then law can make good the claim to provide a fixed point, a reliable standard for citizens in these democracies to use in daily interactions. From Luhmann's perspective, if autopoiesis - is wrong, then the legal system seemingly must succumb, like the market or even the family, to the perpetual warfare over politics and morality that citizens of democracies at once lament and celebrate.

My perspective is different. Politics and morality do not destroy the legal systems of advanced industrial democracies. It is not a mark of success for these legal systems to be able to claim that they are intellectually coherent, hence autonomous from the "nonlegal" pressures of politics and morality. Law in these systems can be another way of playing politics, another arena in which citizens engage in

12. See Jacobson, Hegel's Legal Plenum, 10 CaRdozo L. REV. 877 (1989) [hereinafter Jacobson, Legal Plenum]. 
moral disputation. ${ }^{13}$ The reverse is also true. It is hard to fathom how any politics or moral disputation can function, even in principle, in a universe devoid of legality. The idea is nonsense, inconceivable. Hence, the project of protecting the legal system from a "nonlegal" politics or morality is a false project. Practicing lawyers in common law systems know this truth. Legal scholars, fascinated by the same models of jurisprudence that beset Luhmann, often forget it.

My disagreement with Luhmann also centers on the definition of elements bearing the system's autopoiesis. Luhmann maintains that the autopoietic elements of the legal system are legal norms defined as congruently generalized behavioral expectations (p. 27). Luhmann's definition thus deprives legal norms of any reference to real individuals. Luhmann dumps everything real about individuals into the cognitive part of the legal system, the exact part that is not autopoietically closed according to Luhmann's formula. The common law, by contrast, gives the real individual a role in the content of norms, not just in stating the content. The individual is a necessary normative reference. The legal norm does not stand apart from its maker. To know the norm is to know prior, present, and future applications of the norm by ordinary legal persons. ${ }^{14}$ The norm is the application of the norm. It is not prior to application. 15

Finally, my disagreement with Luhmann may be expressed as an uncertainty, or skepticism, that scientific models such as autopoiesis can fully capture the strong individualism of the common law. Luhmann works in a tradition heavily influenced by positivism and naturalism. These schools of jurisprudence use images of science that have no room for individuality. By looking to autopoiesis, one of the new sciences of the individual, as a model for legal theory, Luhmann tries to ameliorate the lack of dynamism and unity that have traditionally afflicted positivist and naturalist theories. Yet in the end, Luhmann sinks back into the very models autopoiesis was meant to ameliorate. The simultaneous attraction that positivism and naturalism exercise on legal theorists is immensely powerful. Perhaps we do not yet have an adequate scientific model of individuality to ward off that attraction.

13. Roberto Unger's conception of "expanded discourse" captures this idea. See Unger, The Critical Legal Studies Movement, 96 HARV. L. REV. 561 (1983). Unger is fighting a dominant mood in the American legal academy, the bureaucratic legal theory of the generation of legal academics that came of age in the 1950s. He would find widespread agreement with his concep. tion in most law offices.

14. Drucilla Cornell's attack on Luhmann runs along these lines. See Cornell, Legal Positiv. ism, supra note 6 .

15. Positivism and naturalism hold, each in their different yet complementary ways, that the norm is prior to application of the norm. Luhmann claims to agree that lawmaking and law. applying can never, even in principle, be distinguished. P. 345. Nevertheless, the structure of his model, sharply distinguishing normative from cognitive ways of handling disappointed expectations, may lead him into the very distinction he denies. 
Nonetheless, legal theory has a powerful account of individuality in a different tradition: law as revelation has strong models of individuals. At the very least, revelatory law is worth exploring as a possible model for dynamic (and often nonsacred) legal systems, in which the individual as such plays a leading role. The common law puts individuals at the center of the legal system, and possesses recognizable revelatory moments. Law as revelation has never used scientific models.

Part I of this Book Review explores some ties between the nonrevelatory traditions of Western jurisprudence and the preindividualist models of science available to these traditions up to the end of the nineteenth century. Part II describes the new sciences of the individual, which began to dominate science at the turn of the century. These included, at first, developments in physics and psychology, and Weber's social science. Autopoiesis too is a science of the individual, as Part III shows, with precursors in economics and legal theory. Part IV describes Luhmann's vision of autopoietic law and the model of society as communication anchoring it. Part $\mathrm{V}$ argues that Luhmann has retreated from the vision of autopoietic law in order to emphasize the autonomy of legal systems, albeit at the cost of their dynamism. Part VI presents a common law response to the retreat, emphasizing the centrality of dynamism in the legal system of at least one advanced industrial democracy. The discussion of dynamism in the common law turns us to the revelatory tradition.

\section{CONTINENTAL JURISPRUdENCE AND PRE-INDIVIDUALIST SCIENCE}

Science has always been a source of powerful metaphors for Western jurisprudence. ${ }^{16}$ Apart from revelation, the two other main traditions of legal thought, legal positivism and naturalism, stick closely to one of the two scientific traditions that were dominant in the West through the middle of the nineteenth century.

Legal positivism always rests upon the physicists' model of mechanism. Naturalism adopts some version of the biology of species (or essences) that marks pre-modern organic science. Particular theories, such as Hobbes' Leviathan, ${ }^{17}$ have inevitably joined these models in fabulous and instructive mixtures. Nevertheless, these two models,

16. D'Entreves attributes the constant attraction of legal theory to "nature," for example, to "the quest after some immutable standard or pattern, independent of . . . choice and capable of carrying conviction." A. D'ENTREves, NATURAL LAW 16 (2d ed. 1970).

Patrick Nerhot's, The Fact of Law discusses and criticizes the link between legal positivism and positivist science. Pp. 312-34. Many of his observations are similar to mine, especially his emphasis on the mutual dependence of positivism and naturalism, the dynamism of the legal system, and the necessity of recentering values and individuals in legal theory. Alas, he is not familiar with common law.

On the link between law and science in American legal theory, see Yablon, Law and Metaphysics (Book Review), 96 YALE L.J. 613, at 620-22 (1987).

17. T. Hobbes, Leviathan (C. MacPherson, ed. 1951) (1st ed. 1651). 
mechanism and the biology of species, practically defined the images legal theorists drew upon to describe the ways and means of nonrevelatory law and legal institutions.

\section{A. Legal Positivism and Mechanism}

Legal positivism is the doctrine that persons can know law solely by reference to the procedure by which it is marked as law, or promulgated. A key problem in positivist systematics is accounting for the source of the procedure. Some forms of positivism attribute the source to the agreement of persons to be governed by laws promulgated according to the procedure. ${ }^{18}$ Others develop a procedural naturalism, whereby a rational observer perceives the procedure. Perceived procedures often accompany a natural morality. ${ }^{19}$ At least one branch of positivism, therefore, reduces to a naturalism of procedure. The other also remits to naturalism, however, in the question: How do we know when persons agree?20 Thus positivism always requires a naturalist practice, at least whenever the procedural mechanism is beset by conflict or disorder.

Positivism draws two simple images from mechanism. ${ }^{21}$ The first is the static image of order (inertia). The second is the kinetic image of control (impressed forces). Positive law describes a procedure, a mechanism, whereby an observer is able to understand the order established by "orders". emanating from the procedure, and to control legal subjects (the masses) by enforcement of the orders (the forces).

Legal positivism also shares a deep methodological kinship with the methods of experimental science, of which mechanism is a supreme example. (The method of the pre-modern biology of species and naturalism is observation, not experiment.) The way of knowing through experiment resembles the positivist account of legislation. Laws are the subject of knowledge in both experimental science and positivist jurisprudence. The experimenter and the jurisprude come to know laws in a similar manner. Laws are not "found" (as observations are found in the pre-modern biology of species or in naturalism), but are "put there" by acts of will.

Experiment requires two acts of will. The first is the exercise of will in making a theory. The theory contains a description of an initial state in terms of categories, together with a description of laws of motion amongst the categories. These descriptions are an act of will on the part of the experimenter, since the categories and the law of motion amongst them have heuristic value only. (The experimenter does

18. See, e.g., id.

19. See, e.g., E. Fuiler, THe MoraitTY OF LAW 81-82 (1964).

20. See Hobbes' crucial discussion of conscience in chapter 7 of his LEviatHAN, supra note 17.

21. See generally E. NAGel, The Structure OF SCIENCE, 153-202 (1961). 
not claim to know the essence or real being of nature through the categories and laws of motion.) The second act of will is empirical. The empirical act of will is to intervene in the initial state, checking that the actual categorical changes in the state match the changes predicted by the laws of motion. The validity of the theory depends upon the coincidence of the first act of will with the second: the laws of motion described in the theory with the actual state produced by the intervention.

Similarly, legal validity in positivism flows from the coincidence of two acts of will. The first act of will in positivism is the promulgation of laws by the legislator. Promulgation of laws closely resembles the theory-making act of will in experimental science. Positivist legislation at once describes behavior in terms of legal categories, and sets the legal laws of motion - the orders backed by sanctions - amongst the categories. The second act of will is the decision of subjects of law to follow or not to follow the orders, the legal laws of motion. Legal validity flows from a coincidence of the subjects' decisions (whether following orders or triggering sanctions) with legislation.

Finally, both legislator and experimenter-as-theorist in the first acts of will are apart from or "outside" the material they wish to control. Both legal subject and experimenter-as-intervenor in the second acts of will are "connected to" the controlled materials, but are still only tentatively or hypothetically "inside" them. Both legislator and legal subject, therefore, have external orientations toward legal norms. There is never a coincidence of maker of norms and subject of norms. Norms are just "there," instruments of control or subjection, entirely external to all persons in the positivist legal universe.

\section{B. Naturalism and the Biology of Species}

Naturalism is the doctrine that the source of law is the perceptions of a rational observer. The key problem in naturalism is the qualification of the observer as "rational." When conflict inevitably arises over the qualifications of competing observers, naturalism remits to procedural marks of rationality. Thus naturalism requires a positivist practice when the project of locating a natural essence is beset by conflict or disorder.

Naturalism draws the image of a rationally perceivable essence law as substance - from the biology of species, which is whólly open to the perceptions of a rational observer. "Biology of species" refers to any biology that uses "species," however defined, as the building block of the organic, or even inorganic, world. ${ }^{23}$ "Individuals" are

22. See A. D'ENTREves, supra note 16 , at $65-78$.

23. See E. Mayr, The Growth of Biological Thought, 251-98 (1982). On the difference between mechanistic and biological explanation, see E. NAGEL, supra note 21, at 398-446 (biological explanation is usually teleological; mechanistic explanation is not). 
merely the instruments or bearers of the life of the species. Characteristics borne by individuals may or may not capture the species characteristic in this biology (as, for example, individual bees - workers, drones, queen - do not, taken one by one, capture the species characteristic - the hive life - of bees). The biology of species (possibly always) formulates the scientific "explanation" of a phenomenon as an essence, which can be adequately perceived through correct observation. The technique, and therefore the content, of observation varies, of course, from one version of the biology of species to another. Nonetheless, the assertion in this scientific method is that sheer observation can plumb the depths of reality.

The biology of species, unlike experimental science, has no simple test of validity. Similarly, natural law has no clear test, unlike legal positivism. The tests of validity, such as they are, stem either from esthetic intellectual criteria (fitness, elegance, etc.) or from the degree to which the actual life of the species fulfills a purpose the observer assigns to the species, an esthetic practical criterion flowing from the observer's teleology. Failure of a species or group to pass either sort of criterion is chalked up to disease or deformity. Hence legal systems premised on naturalism tend to regard sanctions as either the cure of moral disease or, in the most serious cases of deformity, eradication of the diseased creature.

\section{The NeW ScIENCES OF THE INDIVIDUAL}

Prior to this century, only philosophers and theologians attempted to discuss the individual as such. Scientists spoke about species or categories, not individuals. The approach to the individual as such, both as observer of events and as event observed, is a hallmark of twentieth-century science. ${ }^{24}$ Autopoiesis uses the language of science to talk about individuals as such, not as members of species or instances of categories. It is the most recent addition to the new sciences of the individual, in which truth flows from individuals interacting with individuals, rather than from species and categories in the mind of God.25

Autopoiesis thus depends upon shifts in scientific method that began replacing both mechanism and the biology of species as long ago

24. Like most generalizations, this one begs to be challenged. For example, some eighteenthcentury biologists spoke of individuals rather than species. See E. MAYR, supra note 23, at 26365. Nevertheless, only twentieth-century science has made the points of view of the individual thematic in several branches of science.

25. Stephen Hawking's new book is a model of honest scientific deliberation on the place of God in scientific theories. S. HAWKING, A BRIEF HISTORY OF TIME (1988). For example, he describes the relative latitude Laplace, the arch-determinist, gave to God's operations. Id. at 172. Hawking himself believes that we can come to know the mind of God through understanding the mechanisms of the universe. Id. at 175. 
as the middle of the nineteenth century. ${ }^{26}$ The new discoveries replaced mechanism first with statistical mechanics, then in turn with the theory of relativity and quantum mechanics. ${ }^{27}$ They discarded the method of essences for a biology of individuals, as a consequence primarily ${ }^{28}$ of Darwin's theory of evolution. ${ }^{29}$

The "biology of individuals," by contrast to the biology of species, looks to individuals as the building blocks of the organic, or even inorganic, worlds. Darwin's evolutionary biology, which demonstrated above all the temporality of species, rendered the whole project of perceiving essences untenable (essences probably have to be eternal). The focus had to be on characteristics of individuals and interchanges among individuals. The "species," from this perspective, could only be either a summary description of interchanges or the isolation of specific interchange mechanisms, such as language for humans. Only evolution makes the biology of species untenable. Darwin's scientific predecessors, like the medieval Nominalists, could only assert the impossibility of divining essences; they had not scientifically shown it. ${ }^{30}$

The replacements for mechanism, just like the biology of individuals, also forced scientists to consider the role of individuals in forming reality, both as objects of scientific scrutiny and as the scientist-subjects carrying on the scrutiny. Statistical mechanics makes explicit the abstraction of classical mechanics' description of "forces moving masses." Instead of "forces moving masses," statistical mechanics of-

26. It is characteristic of the conservatism of lawyers, even "radical" lawyers, that legal theory had to wait so long for this reflection. Ideas do not exactly travel at the speed of light in legal theory.

27. See 1 A. D'Abro, The Rise of The New Physics 101-05 (1951) (first published in 1939 as Decline of Mechanism). See also E. SEgre, From Falling Bodies to Radio Waves: Classical Physicists and Their Discoveries 233-51 (1984) [hereinafter E. Segre, ClassiCal Physicists]; E. Segre, From X-Rays to Quarks: Modern Physicists and Their DisCOVERIES 61-100 (1980).

28. But not exclusively. The way had been prepared by Hegel. The biology of individuals forms a basic theme of his Phenomenology of Spirit (1807) and Encyclopedia of Philosophy (1817). However, Hegel's scientific method had no effect, so far as I know, on the developments in science or legal theory that I am describing. The intellectual history would be worth exploring.

29. See E. MAYR, supra note 23 , at 251-97.

30. Montesquieu - like Luhmann and Weber, a lawyer turned social scientist - prefigured the study of populations in the twenty-third book of his Spirit of the Laws, "Of Laws in the Rapport They Have with the Number of Inhabitants," (published in 1748 as De l'Esprit des Lois). Durkheim's elaboration of Montesquieu's population theory was published in 1893 as the Division du Travail Social. See E. DuRkheim, The Division of Labor IN SOcIETY [hereinafter E. DuRkHEIM, Division OF LABOR] 256-82 (1964). The centrality of populations to biologi$\mathrm{cal}$ theory was not at all understood until 1896 at the earliest. See E. MAYR, supra note 23, at 272. We shall see another instance where social science anticipated a development in biological theory, in autopoiesis! See infra note 57.

Hypothetically, one may pinpoint the joinder of Hegel's metaphysical biology of individuals with scientific theorizing in the work of the American pragmatists, particularly C.S. Peirce, in the late nineteenth century. His "science of signs" is an attempt to talk about the specific interchange mechanism of humans. See J. HABERMAS, KNOwLEDGE AND HuMAN INTERESTS 91-112 (1971) (first published as Erkentnisse und Interesse in 1968). 
fers probabilities that an observer will find components of matter, however defined, at a spectrum of points in space-time. ${ }^{31}$ Relativity and quantum mechanics force inclusion of perspectives or actions of the observer as part and parcel of observation. Quantum mechanics asserts that observation sets or distills the observed phenomenon from a fundamentally "nonobservable" substrate, one that is probablistic in nature. ${ }^{32}$ Thus a common theme expressed both in the decline of mechanism and in the substitution of the biology of individuals for the biology of species is the role of the individual, both as subject and object, in the scientific account of reality. ${ }^{33}$

Durkheim represents a transitional figure in the application of the methods of individualist science to social life. Durkheim's method is sheer observation. ${ }^{34}$ Though the method is substantially similar to the methods of pre-modern species science, the object of observation includes individuals as well as species. ${ }^{35}$ Even so, Durkheim's method does not require reference to the observer's perspective, hence any conversation between observer and object of observation. ${ }^{36}$ Max Weber developed the first fully individualist methodology in social science, shortly after Durkheim's work, requiring reference to the consciousness of the observer and a conversation between the observer and the observed. ${ }^{37}$

31. Statistical mechanics thus joined the evolutionary theory of populations as a latecomer to Montesquieu's derivation of aggregate characteristics from populations. Ludwig Boltzmann introduced the formative distinction of statistical mechanics between the average in time on a single molecule and an instant average over many molecules (and proved the equality of these distinct concepts) only in 1871. See E. SEgRE, ClassiCal Physicists, supra note 27, at 242.

32. See generally H. PAGels, The Cosmic Code 17-190 (1982).

33. I have deliberately not discussed the new science of chaos, which incorporates both notions of self-organization and self-similarity through iteration of recursive functions over all elements of a set. Though autopoiesis undoubtedly belongs to the science of chaos, neither the science nor my knowledge of it is sufficiently developed for me to tie the two together. James Gleick reports that some physicists regard chaos theory as the third great revolution of twentieth-century science, after relativity and quantum mechanics. All three chip away at the Newtonian foundation of mechanics: relativity at the absolute Galilean frame of reference, quantum mechanics at absolute measure, and chaos at Laplacean determinism. See J. GLEICK, Chaos: Making a New Science 5-6 (1987). One branch of chaos theory, Benoit Mandelbrot's theory of fractional dimensions, emphasizes the relativity of measure with respect to scale, as compared with relativity's acceleration and quantum mechanic's position. Mandelbrot has emphasized the kinship of his ideas with the twentieth-century emphasis on the perspective of the observer. See id. at 97.

34. See E. DuRkheim, The Rules of Sociological Method 12 (8th ed. 1938) (published as Les régles de la méthode sociologique in 1895).

35. See id. at 6-13.

36. Durkheim's use of the comparative method may be a substitute for Weber's method of understanding through conversation. See infra text accompanying notes 111-13.

37. See M. Weber, The Methodology of THe Social Sciences (1949) (the earliest essay was published in 1904). For a more elaborate discussion of Weber's method, which is the starting point today for all social inquiry, see infra text accompanying notes 111-13. But see infra note 113. Anthony Kronman has emphasized the will-centered, hence individualistic, element of Weber's methodology. See A. KRONMAN, MAX Weber 6-36 (1983). Kronman ties Weber's individualism to his positivism. I believe this misconstrues the revolutionary implications em- 
The most thoroughgoing science of the individual, Freud's dynamic psychology, uses methods clearly reflecting the milieu in which Weber's social science, modern biology, and the new physics flourished. ${ }^{38}$ Only the goal of dynamic psychology differs: the empirical realization of the freedom of the individual, which philosophy, political theory, and law assign to the individual only in principle. The technique of the empirical realization of freedom bears a striking resemblance to the technique of the other sciences of the individual in the empirical realization of truth: a cooperative communicative interaction in the interest of self-knowledge. Only recently has a social theorist, Jürgen Habermas, attempted to follow Freud's program in the three fields against which Freud developed his dynamic psychology. Durkheim and Weber used individualist methods in the interests of knowledge. Habermas uses them, like Freud, in the interests of freedom. Habermas' effort has been critically important in Luhmann's invention of autopoietic law. ${ }^{39}$

The test of validity in the new sciences of the individual is the health of the individual. Health, in turn, is broken down into various notions of functional efficiency. Since the biology of individuals lacks any teleology or canon of intellectual elegance, the degree to which the subject of observation fulfills a moral purpose or satisfies an esthetic vision cannot be defined by these scientists. Nor do they express an interest in control through experiment. Health - the efficient functioning of the organism - uses criteria established by the organism itself. Thus the scientist of individuals necessarily enters into a conversation with the object of observation. The observations of the scientist serve not to control the organism, but to suggest or create conditions in which the organism can maximize functional efficiency as the organism defines it, or to assist the organism in changing its functional criterion, its canon of health. Some scientists of the individual have used a physical or objective version of the test of health that does away with methodological conversation. They observe the "survival" of the organism as if they were mechanists or scientists of species. The objectivity of the test of survival is a "given," rather than a

bedded in Weber's methodology, if not the social theory he actually constructed using the methodology.

38. Freud published the first great work of dynamic psychology, Interpretation of Dreams, in 1900 as Die Traumdeutung. He first used the term "psychoanalysis" (in French!) in 1896. See P. GAY, FReUd: A LIFE FOR OUR TIME 103 (1988). Planck's first paper in quantum theory was published in 1900. Weber's first methodological essay, "Objectivity in Social Science and Social Policy," was published in 1904. See Shils, Foreword to M. WEBER, THE METHODOLOGY OF THE SOCIAL SCIENCES at iii (1949). Einstein and Poincare published their papers on special relativity in 1905. Jordan and Poulton first explored the biological theory of populations in 1896 and 1903 respectively. See E. MAYR, supra note 23, at 272.

For the classic synthetic discussion of the methods of Durkheim, Weber, and Freud, see T. Parsons, The Structure of Social action (1937).

39. See infra text accompanying notes 57-58. 
reward for methodological conversation. ${ }^{40}$

\section{Biological Autopoiesis and its Precursors in Social SCIENCE}

The new description of law and legal institutions, which has been brewing at least since the era of Kelsen and Hayek, has the rather formidable name, "autopoietic law." Autopoiesis - "self-production" - is a term coined by Maturana, a Chilean biologist, to describe an advance in the application of systems theory to organisms (pp. 7174). The autopoietic paradigm is an important contribution to the scientific modelling of individuation.

Autopoietic systems are those in which the elements of the system generate the network of operations producing the elements of the system. ${ }^{41}$ By contrast, a system whose elements do not generate their network of production in the circular manner of autopoiesis is an allopoietic - "other-produced" - system. The elements of an allopoietic system are either fixed (given and unchangeable) or generated by forces or elements from the system's environment. The system is neither independent nor autonomous, since the elements of an allopoietic system do not produce themselves exclusively out of elements of the system. The core image of an allopoietic system is the machine, as opposed to the autopoietic organism. The machine changes when its elements change. It cannot resist change in its operations by transforming its elements. Though the elements of an autopoietic system almost certainly change as other elements generate them, they change

40. Hobbes uses at least three tests of validity in his Leviathan. See supra note 17. The Leviathan prefigured the test of survival. Nevertheless, Hobbes also retains a teleological test of validity, since the Leviathan uses "convenience" as well as survival. Hobbes thus represents a transitional figure from naturalism and the biology of species to the modern sciences of the individual and a form of autopoietic social theory. Hobbes' positivism, I would argue, is a consequence of his naturalism, where Hobbes attempts to deal with the absence of a criterion for determining the status of the rational observer. His ambivalence is clearest in the claims he makes for the laws of nature. At some points he refers to them as rationally observable and deducible - his Spinozism. Overall, however, he remits the validity of the laws of nature to a third test: self-reflection on the part of the reader. This third test, while not thoroughly worked out, resembles the test of health in the modern sciences of the individual.

Malthus was the first to associate Montesquieu's population science with a test of survival. Durkheim uses both a test of survival - in Suicide - and a test of health - in The Division of Labor in Society. E. DuRkHEIM, SuICIDE (1897); E. DurkHEIM, Division of LABoR, supra note 30.

Luhmann, correctly I think, distances autopoiesis from the test of survival. P. 14. Nevertheless, his abandonment of the full force of autopoiesis in the positivistic formula, normatively closed and cognitively open, restores survival as a possible criterion.

41. One of the two discoverers of biological autopoiesis, Maturana, defines it as follows:

We maintain that there are systems that are defined as unities, as networks of productions of components that (1) recursively, through their interactions, generate and realize the network that produces them; and (2) constitute, in the space in which they exist, the boundaries of this network as components that participate in the realization of the network. Maturana, Autopoiesis, in AuTOPoIEsIS, A THEORY OF LIVING ORgANiZATION 21 (M. Zeleny ed. 1981). See supra text accompanying note 2 . 
according to operations (criteria) of the system, not in direct response to outside pressures (the system is "closed").42 The operations of an autopoietic system do not change in response to outside pressures. Change in elements is the cost of maintaining the stability of operations. Hence the autopoietic system maintains its identity as a system $t$ 'rough its operations, even though its elements need not be the same $i_{s}$ successive transformations. Even as its elements change in response to outside pressures (the system is "open"), the system responds to the pressures on its own terms (according to its own operations), not on terms established by the environment. It resists such pressures as $a$ system by transforming single elements, or by uncoupling an environment - running away from the pressure.

The intent of the autopoietic paradigm is to account for the power of organisms to control or affect the environments in which they collectively evolve, and to maintain their identity in the face of pressures from these environments (or select amongst environments). ${ }^{43}$ Ordinarily allopoietic systems can do neither. Autopoiesis thus focuses on attributes of individuation which former scientific methods were hardpressed to explain: self-motivation, or the power of individuals to be a source of force not motivated externally from the environment, and the self-maintenance of individuals in the face of changes in the environment.

Though Luhmann was the first to use autopoiesis explicitly as a paradigm for social theory, ${ }^{44}$ he is by no means the first to use its substance to model social processes. Characteristically, the first grand autopoietic theory arose in economic, not legal theory, the remarkable achievement of Piero Sraffa in his Production of Commodities by Means of Commodities. ${ }^{45}$ Sraffa had begun work on his masterwork in

42. Luhmann emphasizes "closure" as the outstanding characteristic of autopoietic systems for legal theory. See p. 15.

43. $C f$. N. LuhmanN, Differentiation supra note 8, at 36-38.

44. See Luhmann, Autopoiesis, Handlung und Kommunikative Verständigung (Autopoiesis, Action and Communicative Understanding), 11 ZEITSCHRIFT FÜR SOZIOLOGIE 366 (1982). Luhmann had been interested in the idea of self-reflexivity for some time. See, e.g., N. LUHMANN, DifFerentiation, supra note 8, at 229 (collecting essays that had been published as early as 1971). Chapter 11 (at p. 255) appears to have been written especially for this volume. Cf. N. LuHMaNN, A Sociological THEORY OF LAw $164-65$ (1985) (published as the Rechtssoziologie in 1972) [hereinafter N. LuHMANN, Sociological THEORY].

45. See generally P. SRaffa, Production of Commodities By Means of Commodities (1960). Once again, a model thought to have originated in the hard sciences had its real debut in social theory. The autopoietic lawyers do not seem aware of Sraffa's achievement, and attribute the discovery of autopoiesis to biologists. Montesquieu (the theory of populations) and Hegel (the biology of individuals) were not to be the last unheralded pathbreakers for the "hard" sciences. Perhaps all hard science models start in cultural orientations, as Thomas Kuhn has suggested. See T. KuHN, The Structure of Scientific Revolutions $94-95$ (2d èd. enlarged 1970). A nice case of direct impact of philosophy on science is Ampére's discovery of the magnetic effects of electric currents as a consequence of his conviction, learned from Kant, that unobservable theoretical entities could be studied through their interactions. See Williams, $A n$ drè-Marie Ampére, SCI. AM., Jan. 1989, at 90. Lewis Carroll Epstein has emphasized the role of good and bad myths in scientific theory. See L. EPSTEIN, ReLATIVITY VISUALIZED 76-77 (1981) 
the late 1920s, at just about the same time that Kelsen produced his, the Pure Theory of Law (1934). ${ }^{46}$ Kelsen's theory, unlike Sraffa's, is only partly autopoietic. Kelsen, of course, saw every norm as both generated by and generating norms, except the "basic norm" (at the top of his hierarchy of norms) and the "individual norm" (at the bottom). Kelsen's legal theory is thus not fully autopoietic, because norms form a hierarchy, not a circle. His theory doesn't achieve the generative circularity that is characteristic of autopoietic systems, but uses the "basic norm" instead as a generative seed for the dynamic norm-production of the system. Kelsen's theory thus bears a striking resemblance to the economic theory of Ricardo, which uses corn as a "basic commodity" by which all value can be measured in the reproduction of the means of production. ${ }^{47}$ Sraffa trumps Ricardo by using a fully autopoietic measure - a constructed "standard commodity" defining the conditions of reproduction in terms of equations of production rather than in terms of any single basic commodity such as corn, or even Marx's "socially necessary labor time."

Hayek's work in the mid-1970s probably constitutes the first fully autopoietic legal theory. ${ }^{48}$ Hayek, however, self-consciously eschews any scientific model, except perhaps the economic methodology of Mises. ${ }^{49}$ Hayek's is also not a theory of sheer observation, as Luhmann's confinement of autopoietic law within a social subsystem may be, ${ }^{50}$ but rather serves to ground a normative jurisprudence. In this sense, Hayek has already outstripped the autopoieticists in reconciling the conflict between normative work and social science that afflicts all forms of positivism, legal and scientific.

\section{AUTOPOIETIC LAW AND SOCIETY}

Though Luhmann is primarily interested in sociological theories of law, he applies the autopoietic paradigm most convincingly not to law but to the social system. Luhmann's first (and most clearly defensible) assertion is that social systems are autopoietic. His second assertion, which he correctly believes to be more problematic, is that under certain conditions the legal system, as a subsystem of the social system,

(relativity is a natural geometric theory, which can be easily visualized once we have fashioned a good myth for it).

46. H. KELSEN, supra note 4.

47. See M. Blaug, Economic Theory in Retrospect 93-103 (rev. ed. 1968).

48. See 1 F. VON HAYEK, LAW, LEgisLATION AND LIBERTY 93-103 (1973) [hereinafter F. vON HAYEK, VOL. 1]. Jean-Pierre Dupuy appreciates Luhmann's link to Hayek. Pp. 64-68.

49. See generally L. von Mises, EPISTEMological Problems of Economics (1976) (published as Grundprobleme der Nationalökonomie in 1933).

50. At the outset Luhmann denies the origin of the autopoietic paradigm in the consciousness of an observer. See pp. 12-18. Luhmann is troubled, nonetheless, by the need of self-referential systems (including the system of the observer!) to have an account of reality. See p. 338; see also pp. 262-65. 
can be at least partly autopoietic in the manner of the general social system. Hence autopoietic law involves a claim about law and a claim about society.

\section{A. Law and Society}

Almost every statement about autopoietic law can be and is contested in the marvelous essays of Teubner's collection. ${ }^{51}$ Autopoiesis is, after all, a young science, and even its most enthusiastic proponents, such as Luhmann and Teubner, concede that the utility of autopoiesis for legal theory is uncertain (pp. 23, 221-24). Nevertheless, autopoietic law lays down some broad vistas. Viewing them refreshes the soul of even the most theory-weary reader.

The basic idea of autopoietic law is that in certain circumstances, which Luhmann and his co-workers have begun to elaborate, law (and only law) defines what is and what is not law, and every law must participate in defining what is and is not law. By itself, the idea that law defines law and that every law must take part in the defining (a mathematician would say that law is a recursive function ${ }^{52}$ ) is not a novel theoretical proposition. François Ewald traces the roots of the idea to Kelsen's "law of law" (pp. 36-50). Teubner (p. 224) and Luhmann (p. 22) recall H.L.A. Hart's formulation of the proposition that in complex societies law serves the secondary function of recognizing norms that serve the primary function of directing or facilitating behavior. ${ }^{53}$ The real novelty of autopoietic law is that it tracks down exactly what it means for law to define law, and promises to show the exact social, legal, and cultural (but not political!s4) conditions in which law defining law is possible. In other words, autopoietic law embeds H.L.A. Hart's "rule of recognition" or Kelsen's "basic norm," which like all positivist proceduralisms fall from the heavens, in a social practice.

The social practice in which Luhmann embeds the legal recursiveness of complex societies is a vision of society as communication. ${ }^{55}$

51. Especially in the essays of proponents. Compare Luhmann's contributions (pp. 14-33, 345-48) with Teubner's (pp. 217-37), and Deggau's contribution (pp. 128-51) with Nelken's (pp. 191-215).

52. See supra note 33.

53. H.L.A. HART, THE CONCEPT OF LAW (1961) ("rules of recognition"). Hart's theory is even less autopoietic than Kelsen's, since he divides all norms into two great categories, those that generate other norms and those that are generated by other norms.

54. Thomas Heller's piece, Accounting for Law, is the only one in the volume to discuss the politics of autopoiesis directly. Pp. 283-311. I guess the others really believe that the legal system is autonomous, or that God does not play politics in evolution.

55. Luhmann models the legal system as a subsystem of society, where society is itself an autopoietic system whose elements are communications:

The social system consists of meaningful communications - only of communications, and of all communications. It forms its elementary units from the synthesis of information, communication, comprehension, i.e., from the synthesis of three selections, which can be partially (but only partially) controlled by the system. As such element formation always 
Luhmann's account of society as communication is quite striking, and is, by itself, worth the price of admission to Autopoietic Law. 56

His notion has its roots in Habermas' paradigm of communicative action. ${ }^{57}$ Habermas uses "communicative action" to criticize what he considers to be Talcott Parsons' exclusive focus on social relations as functionally coordinated "systems." 58 Communicative action is a regulative ideal immanent within empirical social interaction. It is the setting in which members of a community coordinate action to pursue common conceptions of meaning. As such, Habermas prefers communicative action to system, though system is necessary to "pay the rent" and must be modelled by the social scientist.

Luhmann's notion of communication lacks the critical bite of Habermas' conception. Society, for Luhmann, is communication - a ceaseless expression of information by one and comprehension by another. Luhmann does not oppose communication to system Habermas' anti-utopia. Rather Luhmann opposes communication to action itself, which Luhmann regards as the choice of addressees for communication (action means not communicating to those who are not chosen). Action is thus a "powerfully simplifying self-observation or self-description of the system by itself," 59 which keeps communication, hence society, going. Consequently, no one ideal model of communicative action, such as Habermas' ideal speech situation, deserves pride of place in the signalling interchanges that both motivate functional systems and are facilitated by them. Communication is textured

presupposes society and always continues society, there is no communication outside society and therefore no communication of society with its environment. No man can communicate (in the sense of achieving communication) without thereby constituting society, but the social system itself (precisely for this reason!) is not capable of communication: it can find no addressees outside itself to which it could communicate anything.

P. 18. See also N. LuhmanN, Differentiation, supra note 8, at 73 .

56. Pp. 16-23. Luhmann writes very fast. He also presents a moving target. His writing is a way of thinking, a real dialogue with the republic of letters. One might almost say that Luhmann's oeuvre itself is autopoietic: it unceasingly regenerates itself, maintaining its identity by changing its elements. Thus almost anything one says about Luhmann's thought is bound to be wrong, since he, like quantum reality, leaves a position as soon as one observes him taking it. In other words, he is a great theorist.

57. See $1 \mathrm{~J}$. Habermas, The Theory of Communicative Action; Reason and the Rationalization OF Society 273-337 (1984) (published as Theorie des Kommunikativen Handelns, Band I, Handlungsrationalität und gesellschaftliche Rationalisierung in 1981).

58. 2 J. Habermas, The Theory of COMmunicative ACtion; LifewORLd and System: A CRITIQue of Functionalist ReAson 199-299 (1987).

59. P. 16. As an American, I hate the idea of a system "observing itself." I have the bias of the common lawyer, that people do things, not systems. Nevertheless, Luhmann's sentence makes sense. A system "describes itself" by specifying the exact "routes of communication" describing the system. The system does not describe itself in a blueprint of routes, but through actions that make and remake the routes during the life of the system. Hence, the system describes itself through actions. It is also possible to understand the idea that systems, as opposed to individuals, have actions. The bank teller is everyone's favorite example: customer and teller interact according to patterns dictated by a system. One can't even say that the "creator" of the system dictated the patterns, since she too is fulfilling the prerequisites of a system, and so forth. From the point of view of individuals, system actions are "roles." 
and various. It need not even include speech, certainly not rational discourse, so long as it expresses information calculated to change the understanding (in some way) of an addressee of the communication.

The exact meaning of "law defines law" becomes crystal clear as soon as one formulates the proposition in terms of communication. One cannot make "political" or "moral" statements to a person who expects "legal" ones. A "political" or "moral" statement simply will not register. The statement can certainly have moral or political content - no autopoieticist would deny that most or all legal statements do - but it must be in "legal form" in order for the addressee of the statement, behaving as if she is in a legal setting, to receive it and do something about it. After all, the addressee is on the hook. She requires a legal statement, because she must in turn make a responsive legal statement either back to the maker of the original statement or to a third party. (Think of a purchaser of real property, who needs a deed in order to give a deed to some future purchaser.) When asked for "reasons," she must be able to refer back to an original statement, lest her subsequent statement be rejected by the third party, and so forth.

Autopoietic law is thus more radical than the formulation of either Kelsen or Hart because it insists that every "legal communication" must respond to a prior legal communication, and every legal communication must command a subsequent legal communication. It is also more radical, because it eliminates two very compelling and destructive notions that plague the dominant legal theories. These are the notions of "center" (which we traditionally associate with positivism), and "hierarchy" (which we associate with naturalism).

Luhmann's vision of society lacks the usual topology of social, political, and legal thinking. Hobbes, for example, starts with the image of a level social universe, the state of nature, only to show how it is possible to construct a sovereign out of it. The sovereign is a center, around which the whole of society revolves. Kelsen (less so Hart) imagines a "hierarchy" of norms (their naturalist softening of positivism). Our image of order is indelibly impressed with images of hierarchy and center. We find it difficult to imagine society without them. ${ }^{60}$ Yet doing without these images is exactly what Luhmann strives to accomplish. His social science takes no position on center or hierarchy (see, e.g., pp. 21-22). "Center" is an image, a way we have of talking with each other. "Hierarchy" is another way of talking. We may, of course, behave in accordance with the way of talking, but not because "center" or "hierarchy" are givens. It is even possible that we talk "center" or "hierarchy," while behaving in quite another

60. See N. LuhmanN, Differentiation, supra note 8 , at $287,353-55$ (center), 359 (hierarchy). 
manner. ${ }^{61}$

Law in Luhmann's vision is just "law talk," legal communication. We do not make legal statements to one another because we are obeying the orders of a central sovereign or are reflecting a natural or constructed legal hierarchy. We make legal statements because we wish to have an impact on the understanding of persons who expect us to be making legal statements. Our legal statements form an autopoietic system, in that every legal statement serves to generate the network of operations constituting further legal statements.

\section{B. Legal Theory}

The attraction of autopoiesis for legal theorists flows exactly from its ability to account for two characteristics of individuality: self-motivation (the dynamism of legal systems) and self-maintenance (the resistance of legal systems to outside forces). Legal systems give rise to legal norms in ways that cannot be mechanically traced to forces from the environment, such as politics or religion. Even if a society is utterly stable (even if its legal system fully reflects all possible social forces), certain legal systems still appear to have the dynamic capacity to transform society, or to resist transformation. Social science must be able to describe these systems, and the autopoietic lawyers claim to have discovered a means to do so. Under certain conditions, which the autopoietic lawyers could in principle describe, a legal system can be a source of force in the society. It need not be only the passive instrument of outside powers.

Positivism and naturalism, premised as they are on scientific models giving no active role to individuals either as observers or as subjects of observation, cannot successfully model either component of individuality. With regard to self-motivation, positivism at most promises the independence of the legal system from outside forces, once the power controlling the legal system has used the procedure it offers to set the mark of legality on certain compelling orders. Positivism reduces self-motivation to autonomy. Yet the autonomy of the positivist system is passive, a freedom from outside forces. Positivist autonomy is not active autonomy, not a freedom to be a source of force independently contributing to the array of forces in society. Positive legal systems cannot generate law out of law, from within the system, as an autopoietic system generates elements from elements within the system (pp. 36-50). Positive law is always the result, the instrument, of outside powers - religion or politics or custom. ${ }^{62}$ The legal system

61. I am reminded of the famous response of the governors of the Spanish colonial empire to orders from the king: "I obey, but I do not comply."

62. And, of course, the outside powers have nothing in them of law. Thus politics does not have its laws. It is naked force flowing from unabashedly interested agreements (as if agreement did not require law!). Nor does religion have laws. Religion is the fantasy life, the Sunday hobby, of otherwise law-abiding citizens. 
is open to and at the mercy of its environments. Positivism (at least positivism before Kelsen) always supposes that legal systems make law as mechanisms make things: only in response to inputs from outside the system. Like any mechanism, the legal system is a dead instrument, ready to be wielded by whatever power in society gains control over it.

The only validity the positivists can claim for law is that it does not betray or corrupt the wishes of the wielder of the instrument. But a positive system cannot even achieve this limited autonomy, since the wielder of the instrument can always corrupt it to suit detailed expressions of power in individual cases. Even minor powers, not "wielders of the instrument," can capture it quietly in single cases, unbeknownst to the wielding power. Law as "orders" cannot even achieve order, unless a nonlegal force, such as "habit" in Austin, has already produced it.

The problem in naturalism is the excessive, counter-factual affinity of natural systems for stasis. Natural law is the perception of an essence. By contrast to positivism, the world of naturalism is legal stuff - whether divine laws, human laws, or laws of nature. But laws only express the stuff; they cannot change it. Nor would the natural lawyer want to try. The naturalist judge is always stamping out departures from the expressed essence. The legal system serves to facilitate the impression of the essence on a world always threatening to dissolve into chaos.

Autopoiesis, by contrast, defines a system that generates itself independently from its environment. Autopoietic systems can, in principle, be autonomous, or resistant to outside powers. Applied to law, autopoiesis asserts that under certain conditions laws do indeed generate themselves from laws, not from religion or politics or custom. ${ }^{63}$

We must, of course, inquire - and will inquire - from what point of view the autonomy of the legal system may be a value. The autopoieticists claim that they do not maintain autonomy as a value, and they are correct that the autonomy of legal systems under certain conditions is an empirical fact, which autopoiesis successfully models. ${ }^{64}$

Where positivism suggests a legal system insufficiently protected from outside pressure - too frangible, too porous - naturalism requires the legal system to remain true to an essence refined and ex-

63. Exactly which laws generate themselves in this manner, whether general legal norms or specific applications of norms to single cases, is a critical problem for autopoietic law, especially as an account of the common law. See infra text accompanying notes 114-18; cf. pp. 180-81 (norms can withstand individual, but not aggregate, deviation).

64. Lempert's detailed and illuminating comparison of the absolute autonomy sought by Continental theorists with the relative autonomy sought by empiricist common law scholars is important, and will support a central theme of this Book Review concerning the inapplicability of autopoiesis as it presently stands to common law systems. See pp. 152-90 (especially 178-82). Nevertheless, Lempert agrees that autopoietic law puts its finger on something. See pp. 172-73. 
pressed in a single, unchanging set of norms. The only change naturalism recognizes is corruption of or progress toward the essence - either chaos or reconstruction. Whereas positive systems have no internal life (they lie there like clubs to be wielded by anyone powerful or clever enough to capture or use them), natural systems recognize no life outside themselves. Everything different is diseased, not alive in another way. The essence that laws reflect is an essence precisely because it is eternal (and unchanging, though some naturalists play with the difference). Positivism treats legal change as legitimate - a fresh irruption of power. Naturalism cannot treat change as legitimate, for change always spells the death of the legal system. Autopoietic systems, by contrast, require change. They do not just tolerate it as do positive systems.

\section{LUHMANN'S RETREAT FROM AUTOPOIESIS}

Luhmann's vision of law as a special sort of communication ultimately depends on defining the circumstances in which law talk, as opposed to other ways of talking, is the expected communication. So far in his work on autopoietic law Luhmann has used the model of law he developed in his pre-autopoietic work, $A$ Sociological Theory of Law (1972). ${ }^{65}$ Though Luhmann believes that the two can be made consistent, ${ }^{66} \mathrm{I}$ fear that the old work, which is at once positivist and naturalist in its orientation, detracts from the nonpositivist and non-naturalist potential of the autopoietic model. Luhmann's old work de-centers the individual in the legal system by functionally confining the legal system within a subsystem of the social system. Luhmann finds functional confinement of the legal system useful for elucidating the empirical conditions under which the unity and autonomy of legal systems are possible. But his emphasis on unity and autonomy may represent a retreat from autopoiesis.

\section{A. Luhmann's Pre-Autopoietic Legal Theory}

Luhmann's old work takes the Hobbesian perspective that law is an instrument for the production of order. Like Hobbes, Luhmann attempts a project that is at once positivist and naturalist. Hence, Luhmann does not begin his work with the (now) usual positivist assumption that a procedure has fallen from the heavens. Like Hobbes, Luhmann attempts to account for the natural growth of the procedure from a legal state of nature.

Although Luhmann's account has a more modern style than Hobbes', it has the same basic structure. ${ }^{67}$ Hobbes starts from a legal state

65. N. LuHMaNN, SOciological TheORY, supra note 44.

66. See Preface to N. LuhmanN, Sociological ThEORY, supra note 44, at xii.

67. One little-known fact about Hobbes' legal state of nature is that it is thoroughly legal. It is not a condition of no-law, as many suppose, but a condition thoroughly imbued with legal 
of nature without either a social system or a civilized individual. He then deduces the social structure and the civilized individual from his laws of nature (Hobbes' naturalism). The positivist proceduralism and the civilized subject of the proceduralism are the deductive and empirical result of the laws of nature (Hobbes' Spinozism). Luhmann eschews laws of nature, of course. ${ }^{68}$ Instead, he begins with the civilized individual. 69

The civilized individual at the beginning of $A$ Sociological Theory of Law seeks, as Hobbes' creature, to maximize its convenience by reducing the complexity of and contingency in its environment. ${ }^{70}$ The most powerful engine for accomplishing these reductions, as in $\mathrm{Hob}-$ bes, is the cooperation of other individuals. ${ }^{71}$ These others also wish to maximize their convenience by reducing complexity and contingency, hence there is a "double contingency" in every effort at cooperation. ${ }^{72}$ Individuals have "expectations" as a result of reducing complexity and contingency. Because they do so by cooperating with other individuals, they have expectations of the others' expectations. ${ }^{73}$

These "expectations of expectations," which are fundamental to Luhmann's legal theory, pose special problems of coordination. The key problem is whether individuals are prepared to revise their exptectations when another individual disappoints them - a cognitive response - or whether they are not prepared to revise their expectations - a normative response. ${ }^{74}$ The choice between cognitive and

premises. Hobbes is very clear that the state of nature is characterized by the legal condition in which every man has a right to everything. Most latter-day Hobbesians suppose that the state of nature is one in which no man has a right to anything. This is not Hobbes. But it is Hegel, for example, and it is Luhmann. The project in the Leviathan is to show how a restriction of the natural condition of plenitude of right is possible. The instrument of the restriction is contract. Hence Hobbes' legal theory is a theory of contract. The project for those, such as Luhmann, who see the state of nature as being devoid of legal matter - as a condition of no-right, to use Hohfeld's terminology - is to show how rights may evolve from nothing, typically through the property idea of building up expectations. Hence Luhmann's legal theory, like Hegel's, depends on property rather than contract.

This is not the place to explore the consequences of these positions, but they are obviously quite rich and interesting. See, e.g., Kennedy \& Michelman, Are Property and Contract Efficient?, 8 HoFsTRA L. REv. 711 (1980). Even though Luhmann differs from Hobbes in this respect, the structure of his enterprise, like Hegel's, is virtually identical. The only real difference is that neither Hegel nor Luhmann, unlike Hobbes, believes in the notion of the legal state of nature. They envision a state of nature devoid of justification, not rich with it as Hobbes envisioned. The development of law is then a progressive enchantment of nature through justification.

68. See N. Luhmann, Sociological Theory, supra note 44 , at 10.

69. See id. at 23-24.

70. See id. at 24-26.

71. See id. at 26-27.

72. See id. at 26.

73. See id.

74. See id. at 31-34. So, for example, if I lose a bet on a boxer whom I expect to win, I will revise my expectations of his skill if he loses fair-and-square. My reaction is "cognitive." If, 
normative is not graven in stone. ${ }^{75}$ It is selectively influenced by the development of ever more successful methods of coordination driven by the persistent desire of individuals to reduce complexity and contingency. A crucial step along the path of realizing this desire is the institutionalization of expectations, in which "expectations are based on the presupposed expectations of expectation on the part of a third party."76 Institutionalization allows the formation of generalized expectations over an entire social system, thus stabilizing the expectations of expectations over many parties. ${ }^{77}$ Law is the institution of one method of generalization.

Social systems evolve more effective ways of handling the coordination problem, the natural history of which Luhmann explores in considerable depth. ${ }^{78}$ The mechanisms of natural selection of methods of coordination are the familiar ones that social theory borrowed from Darwin through Durkheim. ${ }^{79}$ The basic technique of selection is the differentiation of functionally specific subsystems of coordination. ${ }^{80}$ The function of law, according to Luhmann, is to offer individuals a method of coordination that coordinates all other methods of coordination.81 Laws are thus "congruently generalized normative behavioural expectations." 82

At the heart of Luhmann's legal theory, therefore, is the notion

however, he threw the fight, I will not revise my expectations of his skill, but will be "normatively" outraged at losing my bet.

75. See id. at $36-40$.

76. See id. at 49.

77. See id. at 64-69. Luhmann's notion of "expectations of expectations" reflects his general concern with the self-reflexivity of social phenomena, which he pursued in depth after the publication of $A$ Sociological Theory of Law in 1972. See, e.g., N. LUHMANN, DifFERENTIATION, supra note 8 , at 324-62.

Luhmann's insight into the self-reflexivity of social phenomena, including legal phenomena, is beginning to be reflected in recent American legal scholarship. See, e.g., Sterk, The Continuity of Legislatures: Of Contracts and the Contracts Clause, 88 Colum. L. REv. 658, 661-65, 699 (1988) (analyzing legislature's expectations about their own expectations and the expectation of contract parties); Sterk, Foresight and the Law of Servitudes, 73 CORNELL L. REv. 956 (1988) (analyzing expectations of owners who enter into servitudes of their own future expectations and the expectations of future owners). The reflection is all the more remarkable since Luhmann's work is relatively unknown here.

Douglas Hofstadter's extraordinary introduction to the effects of Kurt Godel's logic of reflection on the sciences and humanities actually suggests the applicability of the logic of reflection to legal subjects. See D. HofsTADTER, GöDEL, Escher, BACH: AN ETERNAL GoldEN BRAID 692-93 (1980). The major advances in chaos theory revolving around self-reflection gained general exposure only in 1976. See J. Gleick, Chaos: Making a New Science 183 (1987) (Feigenbaum's lectures on the universality of certain recursive scalings). See also B. MANDELBROT, FRACTALS: FORM, CHANCE, AND DIMENSION (1977) (linking recursive effects"in several scientific subjects).

Once again, a social theorist has tied the hard scientists, if not beaten them to the punch!

78. See N. LuhmanN, Sociological Theory, supra note 44, at 103-226.

79. See id. at 103-14; $c$. E. DuRKHEIM, DIVISION OF LABOR, supra note 30.

80. See N. LuhmanN, Sociological Theory, supra note 44 , at 167-74.

81. See id. at 73-83.

82. See id. at 77 . 
that the legal system is a functionally defined subsystem of the social system: the subsystem specializing in coordinating all other methods of coordination. Luhmann's functional definition is characteristically positivist and naturalist for at least three reasons. ${ }^{83}$

First, Luhmann's law is a selection-device for generalizing normative expectations. It takes no position on the substance of norms. All that matters is that law can serve the overriding function of stabilizing expectations through generality. The mark of law is a procedure, whereby methods of generalizing norms are coordinated. But this is the method of positivism - marking law without attention to content. The naturalist point of Luhmann's functionalism is that law does not by itself determine the máterials for generalization. These are provided to law by the evolution and play of societal processes. Law cannot teach; it can only express what is already given. ${ }^{84}$

Second, Luhmann defines "norm," the material law seeks to generalize, as a reaction to disappointment: refusal to adjust one's expectations as a consequence of disappointment. The hinge of the definition is reaction to disappointment. Luhmann excludes aspiration from the definition. The norm states a reaction to disappointment of expectations one has about the behavior of another. It does not express expectations one has about one's own behavior. The norm is otherregarding, even if it is reciprocal. The occupant of Luhmann's legal system, like the occupant of any positivist system, always regards norms as an outsider regards norms - describing the behavior of others. The norm is an instrument of stabilizing expectations about others. It is never the occupant's instrument for relating herself to others. The individual as such is absent from the legal system. Others appear in the degraded condition of satisfying or disappointing expectations. They can never be individuals as such, collaborators in aspiration. "Cross at the green, not in between" is the same to Luhmann as "Be a faithful trustee." We may have different reactions to dishonest trustees than to jaywalkers. Yet both commands are norms, because both take a stance toward disappointment of the expectations set up in them.

Third, Luhmann distinguishes cognitive (prepared to learn) from normative (not prepared to learn) reactions to disappointment. The distinction between cognitive and normative - the "is" and the

83. At the time he published $A$ Sociological Theory of Law in 1972, Luhmann was not at all shy about his positivist orientation. See, e.g., id. at 159-66. He would have been far less comfortable with the thought that his positivism, like all positivism, has a necessary naturalist component. Luhmann's positivism bears careful review, however, since autopoietic law is frankly nonpositivist, and the difficulty for Luhmann is in reconciling his old positivist results with his new nonpositivist inclinations.

84. For example, Luhmann comments on the validity of legislation: "Such passing of law can only occur to the extent that the selectivity itself is used for the stabilisation of law. Positive law is not valid because higher norms permit it, but because its selectivity fulfills the function of congruency." Id. at 156 (emphasis in the original). 
"ought" - is the fundamental distinction of positivism. The proceduralism of legal positivism is a way of fixing a boundary between the two. We choose what we choose to disregard. The distinction favors cognition over normation: one can disregard only what one has already regarded. ${ }^{85}$ Hence positivism, both legal and scientific, always asserts the primacy of cognition. Luhmann's legal theory, like all forms of positivism, favors cognition over normation. ${ }^{86}$ The utility minded creatures of Luhmann's theory are prepared not to learn in order to stabilize expectations, to increase the possibility and efficacy of cognition. As in positivist science, the role of law in positiv. ist legal theory and in Luhmann's is to enlarge the realm of effective cognition for utilitarian ends.

\section{B. Luhmann's Use of the Pre-Autopoietic Theory for Autopoiesis}

Luhmann's vision of the legal system in his old work hinges on the distinction between normative and cognitive reactions to disappointment of expectations. Law serves as a master device for congruently generalizing normative expectations. Luhmann preserves this distinction in autopoietic law, because he wishes to assign a functionally defined role to the legal system as a subsystem of the social system. As Luhmann noticed, his old legal theory works well for the program of functionally confining the legal system, hence preserving its autonomy from the rest of society (pp. 18-19, 26-28).

The formula Luhmann develops is that the legal system is autopoietic for norms, defined in opposition to cognition. The legal system is normatively closed and cognitively open (pp. 19-23). Only norms recursively reproduce themselves in the manner of autopoiesis. Cognition - the application of norms to real disputes and the formation of norms in response to real political, moral, and economic issues - is not legally recursive (pp. 26-31) (though every communication must, of course, play a role in the autopoiesis of the entire social system (pp. 339-40)). The legal system maintains its normative integrity from Luhmann's perspective. When individuals use the legal system to resolve disputes, or legal functionaries give content to norms either by "finding" congruently generalized normative expectations or by hypothesizing them in legislation, then nonlegal forces affect the legal system. It is cognitively open (p. 31).

The role of cognition in Luhmann's pre-autopoietic legal theory is to serve the ends of civilized, utility-minded creatures who wish to maximize their convenience by cooperatively stabilizing expectations. Luhmann's autopoietic legal theory preserves the functional role of

85. The naturalist point here is that what we regard, unlike what we choose not to regard, is not open to choice.

86. And, like all forms of positivism, has a naturalist account of cognition. 
cognition, but adds a new role for the legal system that is special to autopoiesis: its dynamism (albeit debased, from my point of view).

Cognitive openness introduces asymmetries into the legal system. New cases present new problems of norm-application, hence normformation. New social conditions require different responses to old cases. Without new cases and new social conditions the autopoietic system would exist "as pure tautology in total indeterminability" (p. 22). A legal system in which every new case is an old case and for which social conditions are absolutely stable would not be autopoietic. An autopoietic system reproduces its operations through its elements, not its elements through its operations. The legal system, like any autopoietic system, cannot be unless it is in motion (pp. 341-42). The cognitive openness of the legal system, according to Luhmann, drives it into the constant adjustments that make it dynamic, hence autopoietic. But the dynamism does not come from within the system. The self-motivation of the system serves the self-maintenance of the system, its autonomy. Internal reflection on norms serves only the purpose of consistency, or unity. ${ }^{87}$ Real critique that changes norms for reasons other than internal consistency is external critique which the system internalizes on its own terms.

\section{Retreat}

The distinction between cognitive and normative and the functional confinement of the legal system within a subsystem of the social system detract from the force of the autopoietic paradigm for law for three reasons.

First, autopoiesis is a strong model of individuality, maybe too strong to be usefully applied to social systems. Before social science began modelling individuality in the era of Freud and Weber, the individual organism was available only as a metaphor for society. ${ }^{88}$ Theorists regarded the reality of society, following scientific models then available to them, to be either a mechanical aggregate (the school of political economy) or a species being (Hegel, Marx). The individual organism makes a demanding model. (Durkheim, for example, is least convincing when he describes society as an organism in The Division of Labor in Society. ${ }^{89}$ ) The model may, for example, require a political program of either corporatism or institutionalism. It certainly suggests some version of the two ways scientists learn about organisms: structure (anatomy) and function (physiology).

The danger of the model is that it may lead theorists to identify structure with institutions (institutionalism) and function with the sur-

87. See p. 346; N. LuhmanN, Differentiation, supra note 8, at 238.

88. Hobbes describes the "Leviathan" either as an "artificial creature" (mechanism) or as a metaphor. See T. HoBBEs, supra note 17.

89. See E. Durkheim, Division OF LABor, supra note 40, at 260. 
vival of the institutions (corporatism). Social theorists must always be vigilant to use structure and function (if they use them at all) in a more "value-neutral" sense. Thus Mark Gould has defined "structure" as "patterns of social interaction, where violation of the pattern implies (in the ideal case) a negative sanction," and "function" as "consequences of [units'] actions for the system as a whole." 90 These "value-neutral" definitions of structure and function do not assume that "society" is striving to preserve structures through functional solutions of structural "problems." Luhmann has consistently strived to use definitions of structure and function that avoid the teleology of the classic functionalism of Durkheim.91

As a most demanding model of the organism, autopoiesis may not be consistent with a nonteleological functionalism. ${ }^{22}$ The very point of autopoiesis is to model the self-maintenance and self-motivation of individual organisms. Autopoiesis thus takes a position on the "consequences of [units'] actions for the system as a whole." Autopoietic functions must strive to preserve structures, and autopoietic structures change in purposive directions. This is all well and good for the real biological individuals autopoiesis was originally meant to describe, but runs dead against the "value-neutral" definitions of structure and function which Luhmann still has a commitment to use. To accept autopoiesis as a model for social systems may involve adopting a corporatist or institutionalist politics and a teleological functionalism which Luhmann, for one, may not welcome.

Luhmann could, of course, maintain his commitment to "valueneutral" definitions of structure and function were he to confine autopoiesis to the individual actor in the social system. There is no theoretical reason why the autopoiesis of the individual could not be broadened to include speech and actions that sociologists ordinarily classify as social action. Indeed, Hayek's version of autopoietic law does exactly this. ${ }^{93}$ So long as one maintains the nonindividualist status of values, as Hayek does, the realm of the social can be preserved. Values are then part of the material substrate on which individuals autopoietically maintain themselves. But Luhmann does not wish to locate society in an account of values, which he believes require a level of cohesion that pluralist and conflict-ridden advanced industrial de-

90. M. Gould, Revolution in the Development of Capitalism: The Coming of THE ENGLISH REVOLUTION 3 (1987).

91. See, e.g., N. LuhmanN, Differentiation, supra note 8, at 241-42.

92. Nor, for that matter, may Luhmann's pre-autopoietic version of autopoiesis, his notion of "self-reflexivity," be consistent with a nonteleological functionalism. See, e.g., the highly teleological language in N. LUHMANN, DIFFERENTIATION, supra note 8, at 236. Luhmann treads on especially dangerous ground when he applies "self-reflexivity" to function. See id. at 238-39.

93. See 1 F. von HAYEK, supra note 48 , at 46,$048 ; 3$ F. VON HAYEK, LAw, LEgisLATION AND LIBERTY $158-59$ (1979). 
mocracies will not support. ${ }^{94}$ Instead, he prefers to locate society in communication, ways of talking about values among other issues. ${ }^{95} \mathrm{~A}$ social theory anchored in values can tolerate, or even welcome, the individual as a counterweight to values - the specification or working out of values in interaction. Norms - including legal norms - play the role in these theories of mediating between values, on the one hand, and individuals oriented toward values in concrete interactions, on the other. ${ }^{96}$ Luhmann's theory of society as communication tolerates neither values nor individuals. Values for him are what the individual desires, rather than what is desirable. ${ }^{97}$ Individuals are the desiring creatures of Hobbes' utilitarian calculus, rather than moral beings wrestling values into action through norms. ${ }^{98}$

Communication replaces both values and the moral beings oriented toward values through norms. The self-reflexivity of communication, communication about communication, replaces norms as the chief integrating mechanism of society. ${ }^{99}$ Given Luhmann's goal of subordinating both values and individuals in social theory, confining autopoiesis to the biological individual would destroy the social theory of autopoiesis, as Luhmann understands it. ${ }^{100}$ The common law requires reference to both, we shall see, values and individuals. It is dynamic, rather than autonomous. Hence, Luhmann's social theory is not likely to be adequate to describe it.

Second, assuming the propriety of the autopoietic model for society, it is difficult to imagine an autopoietic subsystem of an autopoietic system. ${ }^{101}$ The functional definition of subsystems has its roots in Durkheim's conceptualization of the "division of labor" as a second device for social integration besides the "mechanical solidarity" of

94. See N. LuhmanN, Differentiation, supra note 8, at 73-74.

95. "ISJociety is the comprehensive system of all reciprocally accessible communicative actions." N. LuhmanN, Differentiation, supra note 8, at 73 (emphasis in original).

96. See M. Gould, supra note 90, at 5-8.

97. See N. LuhmanN, Differentiation, supra note 8, at 97, 250-51. I am grateful to Mark Gould for pointing out to me the difference between "desired" and "desirable."

98. See Luhmann's criticism of Durkheim's emphasis on the moral problem of sociology in id. at 7-10. Luhmann is quite clear that the role of the person in autopoietic law is to serve "merely [as] a point of allocation and address." P. 339. This is the classic positivist notion of the person - a legal accounting device for reconciling the double entry accounts of action and sanction. The autopoiesis of the social system (hence legal system) must serve higher levels of complexity reduction than the person, who, admittedly, has her own subordinate level of autopoiesis in "consciousness." See p. 339.

99. See N. Luhmann, Differentiation, supra note 8, at 100-02, 349-50.

100. Hayek's is the model of an autopoietic theory that puts values and individuals, mediated by norms, at the center of social theory.

101. Teubner has especially focused on this problem. See pp. 217-41. I shall not try to wrestle here with Teubner's fascinating use of the "hypercycle," and his thesis that legal autopoiesis suggests the internalization of the evolutionary mechanisms of law. They are worth detailed study. See also pp. 361-67. 
common language (perceptions) and values. ${ }^{102}$ The social groups that form around performance of a common function are bound together both by performance of the function and by a "second" tier mechanical solidarity, or common language and values oriented toward performance of the function, called occupational solidarity. ${ }^{103}$ Neither performance of the function nor occupational solidarity by itself yields an autopoiesis of the functionally bound subgroup (just as a social system with only mechanical solidarity cannot be autopoietic). The functionally bound subgroup has an autopoiesis only if it constitutes a social system within the general society, much as the cell forms an organism within the larger organism made up of cells. But the autopoiesis of the subgroup could not operate solely over the functional thematization of the subgroup within the larger society. A "legal subsystem" has an economy, a power structure, etc., but these interchange mechanisms of the "legal subsystem" would thematize power and money in their communications, not law. The acid test of the subsystem will always be whether it is successfully meeting the functional demands of the social system. The subsystem earns money, gets power, by meeting functional demands. Even a highly differentiated legal subsystem cannot obviously maintain the absolute control over production and reproduction of the legal code that autopoiesis requires. ${ }^{104}$ Even if a subsystem could, the autopoiesis of legal communications must also constitute an autopoiesis of the general social system of communications if the social system is to maintain its own operative unity and autonomy. Communications can serve two masters - "payment" can have both an economic and a legal significance (pp. 342-43) - but can be loyal to only one of them.

Luhmann is aware of the difficulty of imagining an autopoiesis of function-specific communications in the context of an autopoietic social system (p. 19). Luhmann thus confines legal autopoiesis to maintenance of a code, the integrity of a system of legal communications (pp. 25-26, 347). The effects of the code on "nonlegal" actions and communications - actual decisions of cases, bargaining in the shadow of actual decisions, the content of the normative elements of the code - need have no integrity, since they do not affect maintenance of the code. The legal system is normatively closed and cognitively open. Luhmann solves the subsystem problem quite cleverly by compressing law into language - legal communications. Actual decisions, bargaining in the shadow of decisions, the content of norms - everything we ordinarily regard as important about legal systems - is not law,

102. See E. Durkheim, Division of LABOR, supra note 30 , at 70-111.

103. See id. at 10-31.

104. "The law's autonomy is in danger only when the code itself is in danger - for instance when decisions are taken in the legal system itself increasingly according to the difference between beneficial and harmful rather than the difference between legal and illegal." P. 347 . 
according to Luhmann, but nonlegal communication and action in the form of legal communication. Because Luhmann cannot allow legal autopoiesis to "disrupt" the autopoiesis of the social system, he must regard law as form only, the legal franking of a nonlegal, autopoietic social substance. The positivism of Luhmann's autopoietic law is the autonomous code; the social substance the code bears is the natural law of the positivism.

Third, even if one can conceive of an autopoietic subsystem of an autopoietic social system, Luhmann's assignment of law to a subsystem bristles with difficulties. ${ }^{105}$ Luhmann's argument for an autopoietic legal subsystem is empirical: under conditions of functional confinement, and only under those conditions, legal communications form an autopoietic subsystem, characterized by the autonomy and unity of legal communications. The empirical test is whether any social system in fact compresses law into the autonomous code that Luhmann's functionalism requires. If the answer is that no social system does, then Luhmann's characterization of the "legal system" as an autopoietic subsystem is a deliberate choice freighted with normative consequence. We can surmise that Luhmann has exercised this choice in order to forward a program of suppressing the role in social theory of values and individuals, mediated by norms. Modelling the "legal system" as a social subsystem is simply not an option for social theories that put values and individuals, mediated by norms, at the center. The consequence for legal theory of de-centering values and individuals is at once positivism and naturalism. The consequence for social theory is a reification of legal institutions and an "evolutionary" preference for the autonomy and unity of legal systems.

For an empirical test whether functional confinement of the legal system is a necessary precondition of its autopoiesis, hence whether autonomy is a more important virtue for the legal systems of advanced industrial democracies than dynamism, we turn to the legal system of our advanced industrial democracy: common law.

\section{Vi. Response of a Common law Denizen}

The notion of a self-generating legal system should be familiar to lawyers trained in our tradition. Common lawyers are comfortable with the thought that the appropriate references for justifying legal decisions are prior legal decisions of the same order, and that every decision serves as a reference for future decisions. This is not a com-

105. So far as I know, Luhmann is the only major social theorist who assigns the legal system to a subsystem of the social system. Luhmann's is clearly the work of a lawyer. Habermas treats the legal system as part-system, part-lifeworld. See, e.g., Habermas, Law and Morality, in 8 THE TANNER LECTURES ON HUMAN VALUES 251-59 (S. McMurrin ed. 1988) (criticizing Luhmann's positivisim and functionalism). 
plete or sufficiently accurate description of the common law. ${ }^{106} \mathrm{Nev}$ ertheless, the common law at least superficially validates some version of autopoiesis. It is thus a good candidate for empirical validation of Luhmann's insistence on functional confinement of the legal system to achieve autopoiesis.

The conception of a self-generating legal system is as familiar to common lawyers as it is bizarre to lawyers trained in the Continental traditions of positivism and naturalism. (Luhmann's work should be much more radical and surprising to his European colleagues than it is to us.) These latter traditions model law on the basis of sciences that have no room for self-production. ${ }^{107}$ The materials of naturalist or positivist systems never trace their origins, as the common law does, to materials produced by the system. Positivist or naturalist materials ultimately come from outside the legal system proper, through the auspices of legislation or natural reason, which in turn are based upon morals and politics, not legal materials. It sometimes seems as if Luhmann has used autopoiesis to rework the traditions in which he was trained in order to fit a common law model.

However, with some notable exceptions, such as Karl Llewellyn, Americans have been shackled by the absence of an adequate model for the common law in positivism and naturalism. The Continental tradition has always supplied the "high talk"108 of American jurisprudence, the common law, its language of serious business. But positivism and naturalism are high talk only. They completely miss the ceaseless self-generative, hence self-transformative, activity marking the common law above any other jurisprudence. Autopoietic law, though another import, provides a clearer reflection of our jurisprudence than do the older models. Yet Luhmann's functional confinement of autopoietic law does not provide an absolutely clear reflection. For that we must tinker with autopoietic law using a tradition we have lost sight of in modern legal theory: law as revelation.

My thesis is twofold. First, any fully autopoietic legal system must include the individual as such in the self-generating operations of the system. Second, any legal system that puts the individual at the center must resort to some version (which we can specify) of law as revelation. ${ }^{109}$

106. See infra text accompanying notes 115-19.

107. See supra text accompanying notes 17-24, 61-66.

108. See The Variorum Edition of The Poems of W.B. Yeats 622 (P. Allt \& R. Alspach eds. 1957).

109. Lempert too suggests a critique along these lines. See pp. 166-68, 173-75, 186. He, by contrast, prefers to couch the critique in terms of the failure of autopoietic law to provide room for legislation. Lempert emphasizes the importance in Anglo-American law of equal access to the legal system by individuals and the status neutrality of law among individuals (pp. 166-68), but he does not turn these emphases into a critique of Luhmann. Nonetheless, Lempert's version and mine are really two sides of the same coin: Luhmann maintains the autopoiesis of legal 


\section{A. Luhmann's Invitation}

Though Luhmann's version of autopoietic law does not provide an absolutely clear reflection of the common law, Luhmann would never claim that it had to. Autopoiesis, first off, is not a model of the common law alone, but of legal systems in advanced industrial democracies, most of which are not common law systems. Bentham, Hegel, Weber - every heavyweight but Hayek who has considered the matter has found it puzzling that the first industrial economy arose in a jurisdiction whose legal system is as barbaric and irrational as the common law. The scientific (to Hayek, constructivist and autocratic!) codes of Continental legal systems seem to fit the rational-legal requirements of modern enterprise much better. Luhmann could, if he wished, join Bentham, Hegel, and Weber by treating the common law as an exception to these requirements. 110

Then there is the matter of method. Luhmann is a scientist; autopoietic law is a scientific model in the tradition of Weber. ${ }^{111}$ The test of such a model, as we should expect of a science of the individual, is

systems in advanced industrial democracies only by contracting them within a functionally defined subsystem of the social system. P. 174. Only my emphasis differs from Lempert's.

The link between our approaches is that once one has made individuals into tenants of their own legal system, then the law they make as individuals appears only as legislation. The legal system necessarily regards legislation as unpredictable, external, foreign. (Ronald Dworkin has recently tried to build a bridge between individuals and legislation through his notion of law as integrity. See LAW's EMPIRE 151-275 (1986).) Disseized individuals avenge themselves legislatively upon the legal system in at least three ways. Acting en masse through interest groups they enact statutes; as judges they make laws in the guise of deciding cases; they make contracts as personal legislation.

I prefer to couch the critique in terms of the absence of individuals rather than legislation, because I believe it brings us closer to understanding a real dynamic underlying modern legal systems that sociologists of law (not to mention legal theorists) have neglected. Though we can mince words on the subject, it is best to treat this dynamic in terms of its purest and most explicit historical expression, which is revelation. See infra text accompanying notes 121-22.

110. I am on Hayek's team. He answers the "English question" of political economy by exploring the exact means by which the common law supported the expansion of industry. See 2 F. VON HAYEK, LAW, LEGISLATION AND LiBERTY 107-32 (1976).

Weber understood and respected the common law as a political phenomenon, but did not, so far as I know, grasp its connection with the development of the English economy in the century following the Bubble Act (1720). See M. Gould, supra note 90, at 430 n.4. The Bubble Act cut firms off from their formal connection with the sovereign through the regulated company, driving them into a common law underground, which became the modern law of associations. See Jacobson, The Private Use of Public Authority: Sovereignty and Associations in the Common Law, 29 BufFalo L. ReV. 599, at 662 (1980). Weber looked to the "Protestant ethic" rather than to law for a transformation in patterns of capital accumulation. The formula is: the common law is unpredictable (unlike scientific legal systems), capitalistic enterprise requires a predictable legal system, the common law hindered rather than helped the development of capitalistic enterprise. Hayek turns the formula upside-down: scientific legal systems may be predictable (often as not they are wildly capricious), but their very "predictability" stifles enterprise.

Ask Wall Street entrepreneurs whether they favor "predictable" legislation and administration of financial transactions out of Washington over those last relics of the eighteenth-century English corporate bar sitting quietly in Wilmington, Delaware. See generally Bratton, The New Economic Theory of the Firm: Critical Perspectives from History, 41 STAN. L. Rev. - (1989) (forthcoming).

111. See M. WEBER, supra note 37. See also supra text accompanying notes 34-37. 
whether it helps disinterested observers "understand" the world in which people think they live, so that decisions they make, together or separately, appear meaningful or rational to the observers. The observers' understanding must, in turn, be comprehensible to the people observed, but may not simply restate their self-understanding. The understanding must be an observation that the observed receive with their own understanding. (Here social science mimics natural science, where the test of validity is universal agreement on the basis of common observations. The difference is that universal agreement in social science includes agreement of the object being observed.) The observed's understanding of the observers' understanding will have fresh insights (about observers too!), requiring fresh efforts of understanding. ${ }^{112}$ Also, the self-knowledge the observed obtain in cooperation with the observers may lead to changes in the way the observed carry on their lives, requiring further cooperative efforts of understanding, and so forth. ${ }^{113}$

The application of autopoiesis to the common law passes Weber's test with flying colors. Luhmann uses autopoiesis to understand in a fresh way the fact that legal systems in advanced industrial democracies are at least partly self-referential, and the references of these systems are never fixed, but constantly changing. We denizens of common law systems understand in our own way Luhmann's understanding. Autopoietic law need not be a perfect reflection of the common law to pass Weber's test, only a recognizable one, and Luhmann's reflection is certainly recognizable.

A recognizable reflection of a social phenomenon, according to Weberian science, invites the denizens of the phenomenon to respond to the understanding. Let us accept Luhmann's invitation. He has suggested an insightful understanding of the legal systems of advanced industrial democracies that we common law denizens can understand. The common law strives (in a manner we shall have to pin down) to be

112. This will, in turn, lead to self-knowledge on the part of the observer and further selfknowledge on the part of the observed. Readers will recognize this as Habermas' integration of Freud's and Weber's scientific methods. See J. HABERMAS, supra note 30, at 261-62, 292 (1971).

113. Social science, Luhmann notes, has its own autopoiesis. Pp. 347-48.

The grand alternative to Habermas' synthesis of Freud's and Weber's conversational method stems from Marx. Marx's methodology retains allegiance to the Baconian tradition of experimental science - an effort to isolate the "laws of motion of capitalism" through the coincidence of a theoretical and an empirical act of will. See supra text accompanying notes 21-22. The danger, of course, of retaining allegiance to the methodology of mechanism is that it will slide into positivism. Marx's early writings maintained an allegiance to the other tradition of scientific knowing before the modern sciences of the individual: the observational method of species science (his notion of "species being"). Mark Gould has argued that Marx avoids positivism (and thus retains the species commitment of his early writings) by insisting on proper experimental conditions for attaining knowledge in social science. Gould describes the conditions in which valid social knowledge is possible as those of an "equitable society." The equivalent of an "experiment" from this point of view is, of course, political action. See M. GouLD, supra note 90, at xvii-xviii. 
self-referential, and the common law constantly engages in selftransformation.

\section{B. A Common Law Model}

Luhmann's account of autopoietic law does not show that he understands the exact manner in which the common law is self-referential. (Perhaps he has not tried.) It also does not show that he understands the reason the common law constantly engages in selftransformation. (He should want to know.) Luhmann may not understand these matters, I suggest, because he has not freed himself from the positivist and naturalist orientations his tradition requires.

As a probable consequence of his dependency on physical or naturalistic models, Luhmann misses the method and motor of common law self-generativity: the role of individuals - ordinary legal persons - in generating legal norms, and the need of individuals to keep transforming them. It is probable (though not certain) that inclusion of individuals in a model of law prohibits the functional confinement of law to a subsystem of the social system. Thus the common law exhibits an expansive, world-filling dynamism constantly pressing to break the bounds of functional confinement. ${ }^{114}$

The difficulties Luhmann faces may not be endemic to autopoietic law, but only to Luhmann's use of it to respond to the peculiar (though widespread) concerns of his own tradition. Luhmann may have committed the noblest sin of social science: constructing an illuminating ideal type of a general phenomenon (the legal systems of advanced industrial democracies) and confusing the general phenomenon with a particular version of it. But the best social scientists, like Luhmann, commit sins precisely in order to have denizens correct them.

The common law reflection of autopoietic law starts from the notion of law in common law systems. ${ }^{115}$ The common law regards the legal norm as a compendium of applications of the norm by individuals in ordinary interactions. (An anchor of the idea that law is application is the doctrine of precedent: legal norms cannot exist apart from specific applications.) Law as application is a profound and far-reaching notion with four immediate consequences.

First, one who wishes to know a legal norm can start knowing it only by studying prior applications of the norm. Thus, reports of

114. See Jacobson, Legal Plenum, supra note 12. The common law is one of three dynamic jurisprudences, sharing a host of characteristics that set them against the two static jurisprudences, positivism and natural law. The most striking characteristic of the dynamic jurisprudences is that, unlike positivism and naturalism, they do not require a stable correlation of rights with duties. They are "correlation-breaking." For a full account of the differences, see $i d$. at 879-83.

115. For a more elaborate account of these ideas, see id. at 886-91, 902-06. 
cases, not black-letter rules, are the first place to look for rights and obligations. Cases sometimes state "rules," but rules are not norms, only a way of talking about the formulation of norms in cases. The norm is the rule-anchored-in-cases. A rule applied in a prior case was the rule for that case, and the doctrine of precedent demands only that it be considered in subsequent applications.

Second, one can know a legal norm completely only once one has completed one's own application. Common law norms are the procedure for their own application. The legal norm is procedurally thick and substantively indeterminate. To know the norm one must study a book of cases rather than a treatise setting forth general statements. The legal norm thus changes as those who are applying it in transactions proceed with their application. At the beginning of a relationship the "rule" component of the norm may be all the guidance law can or should supply to the parties in the relationship. The relationship itself is of a level of abstraction coordinate with the rule. As the relationship evolves, the fullness of prior applications of the norm become more relevant to the parties, precisely because their own application has more materials to compare to prior applications.

Third, the legal norm is the product of the prior applications and the present application. Hence the norm must change with every fresh application. Every application, no matter how routine, must be added to the book of cases. Even an application "on all fours" with prior applications contains the valuable information that the norm has not changed despite changes in the world since the prior applications.

Fourth, the legal norm may change only in certain directions in the fresh application. The common law constraint on changes in norms stems from an overriding common law norm that derives from the definition of law as application. Individuals using norms to conduct relationships must not behave as if the rule-component of the norm protects them, no matter how bad the consequences. ${ }^{116}$ Individuals must apply the norm as if the application is reciprocal. ${ }^{117}$ Judges, after all, are at least partly free to change the rule component of the norm. ${ }^{118}$ Even if they do not, judges and juries may disappoint ab-

116. We traditionally classify the revisionary power of the common law under the rubric of "equity." Though equity and law were institutionally separate in common law jurisdictions (and still are in some), the infuence of equity on common law courts has always been profound. Since the joinder of equity and law, the revisionary power has unambiguously been the province of common law judges. I do not believe, in any case, that the development of a separate equity jurisdiction in the Middle Ages was adventitious. The English legal system included both equity and law, and I refer to the entire system as the common law.

117. Lest Luhmann complain that my account of reciprocity in the common law constitutes a naturalistic "super-norm" (p. 18), I emphasize that reciprocity flows from the definition of law in common law systems as application. In any case, Luhmann himself bases the legal theory in $A$ Sociological Theory of Law, supra note 44, hence by implication in his autopoietic works, on the notion of reciprocity contained in the conception, "expectations of expectations" - a naturalistic super-norm underpinning Luhmann's positivism. See also supra note 95.

118. Anthony D'Amato, in a remarkable prefiguration of Luhmann's work in autopoiesis, 
stract a priori predictions about the application of the norm. Individuals must always impress judge and jury that they have the character of acting reciprocally in their dealings. Respect for the latent rights of individuals who appear to be losers under the rule-component of a norm is an essential component of that character.

\section{Common Law Autopoiesis}

The model of the common law as application suggests a motor for the ceaseless self-transformation of legal norms in common law jurisdictions. The same motor almost certainly applies generally to the legal systems of advanced industrial democracies. The common law motor - the need of individuals as moral beings to engage in constant transformation of law defined as application - supplies a more satisfactory explanation for the perpetual motion and transformation of legal systems than Luhmann's, which reduces to tautology rescued by utilitarian functionalism.

The model also suggests the exact manner. in which the common law is self-referential. The norm includes orientations toward the norm of each individual applying it. Common law self reference requires reference to the selves disclosing themselves through prior applications. This latter reflection, I suspect, is less clearly responsive to Luhmann's model in terms that would be useful or meaningful to theorists working in his tradition. Only they can say.

The role and needs of the individual in common law systems link the motor of transformation in the common law with the manner in which the common law is self-referential. Luhmann's focus on autonomy and order misleads him into eliminating or suppressing the role of the individual in autopoiesis. The elements of autopoiesis in his model are legal communications; the elements in common law, individuals revealing themselves in norm application (understood as norm creation). Because Luhmann focuses on the autonomy of legal systems and the contribution of legal systems to order, he contracts the legal system within the social system to the point where the individual as such is not a recognizable part of it. Inasmuch as individuals figure in Luhmann's model, they are the weak ones of utilitarian dogma, designed only to support the functional contraction of the legal system. The common law both serves and breeds very different sorts of individuals.

The realm of the social does not disappear in the common law

has described the pragmatic restraints on judges' freedom. D'Amato argues that the popular perception of the Realist formula, that law is what the official in charge of enforcing it will do, needs correction. The enforcing official will pay close attention to the predictions of what she will do, since to depart surprisingly from the predictions would diminish her power. Hence the correct formula is that of Holmes: law (for judges as well as lawyers) is a prediction of what the judge will do. See D'Amato, The Limits of Legal Realism, 87 YALE L.J. 468 (1978). 
simply because the common law underscores the fate and needs of individuals. First, individuals figure in the common law only in the character they display through interaction oriented toward the values expressed in prior applications of norms. The individuals applying norms may have hosts of attitudes (personality, emotion) toward the application. The attitudes do not matter: only the display of character in interaction matters.

Second, the prior applications of norms to which individuals orient themselves necessarily include the characters expressed by other individuals in exemplary interactions. These prior expressions of character are themselves orientations toward values expressed through interaction. Hence the individual looking toward prior applications necessarily orients herself toward values expressed in prior applications. The values remain values, even though they include references to character.

Third, the overall orientation of persons living in common law systems - reducing the uncertainty of the application of norms through reciprocity of application - creates communities of norm application, congeries of persons conspiring to set parameters of application. The common law frees individuals to form partial and shifting communities defined by the mutual interest of individuals in specifying law (construed as application) for these communities. The common law sets up parameters of interaction under which individuals have an interest in constructing communities. The "social" in the common law appears as community, not structure.

Common law jurisprudence is not the only jurisprudence underscoring the fate and needs of individuals as members of communities. The common law interest in individuality - the display of character in interaction - is not the only possible interest. Other sorts of jurisprudence historically have emphasized different interests in individuality with a different vision of the social associated with each interest. One interest, for example, has been the self-perfection of individuals, usually found in jurisprudences emphasizing the duties of legal persons over their rights. The vision of the social associated with the interest of self-perfection is the cult, the society of members united in a quest for self-perfection. Another interest has been the liberation of individuals, emphasizing the rights of legal persons over their duties. ${ }^{119}$ The vision of the social associated with liberation is the association of property owners united by mutual recognition of right. These other interests are certainly found alongside common law jurisprudence in the American legal system. For example, American constitutional law emphasizes the interest of liberation. Nonetheless, the common law makes only one interest and its associated vision of the

119. See Benson, Abstract Right and the Possibility of a Nondistributive Conception of Contract: Hegel and Contemporary Contract Theory, 10 CARDozo L. REV. 1077 (1989). 
social thematic: the display of character in interaction and communities of norm application. ${ }^{120}$

The specific vision of the social in the common law does not at all support Luhmann's distinction between normative and cognitive. The distinction is not even theoretically conceivable, which is the most Luhmann claims for it. Every normative reference absolutely requires cognition of the behavior of the legal person applying the norm in interaction. Every cognition of action is steeped in normative reference. The institutions of the common law facilitating this absolute unity of the normative and cognitive are quite elaborate, and bear careful scrutiny. The contributions of the jury, for example, have been inestimably important in warding off the tendencies of bureaucratic legal personnel to degrade the common law to a mixture of positivism and naturalism. The struggle over the directed verdict is only one procedural manifestation of the battle against the degradation of the common law. The jury has also undoubtedly stiffened the resolve of the bureaucratic personnel to use equitable criteria even where litigants do not have a right to trial by jury. Another example is the extraordinary success of constitutionalism in the United States and Great Britain, which almost certainly depends on a substructure of common law litigation and a common law understanding of the nature of right. These examples, unfortunately, exceed the scope of this essay.

The emphasis in the common law, which is at once intensely individualistic and communal, is more likely to support the operations of advanced industrial democracies than legal systems whose structure opposes amoral, want-seeking creatures to a social structure functionally designed to funnel and bridle the depraved activities of these creatures. The first modern industrial system did not arise in a common law jurisdiction by accident.

\section{Common Law Revelation}

Neither Luhmann nor the common lawyers have been without materials in the very core of Western jurisprudence with which to understand the role and needs of individuals as such in legal systems. Though neither positivism nor naturalism does the job, Luhmann's tradition, in common with ours, offers a third model of law, law as revelation, in which the role and needs of individuals as such are central. Revelatory law is a model that legal theorists and sociologists have tried very hard to ignore, but it is worth understanding in the interests of science. Only the revelatory tradition, not positivism or naturalism, contains strong models of individuals that help us understand the motor and method of common law self-generativity.

120. For a more elaborate account of the three individualist jurisprudences, see Jacobson, Legal Plenum, supra note 12. 
The notion of revelation - God speaking directly to (or through) a legal person (or persons) - is a crucial element of all historical legal systems, and the science-based legal theories we have seen so far, including Luhmann's version of autopoietic law, can be an accurate description only of a legal system that ruthlessly eliminates all forms of revelation. None does. The theorists of legal autopoiesis, like virtually all their scientific forebears, are guilty of the Enlightenment crime of excessively hating religion, to the degree that they refuse to theorize it. ${ }^{121}$ Hence they have failed to recognize revelatory moments in ordinary, modern, nonreligious legal systems - God (properly defined) speaking to or through legal persons one way or another.

What is at stake in the banishment of revelation from the scientific approach to law is the career of the individual. Though autopoiesis gives the individual more of a role in the legal system than either positivism or natural law, the legal person of autopoiesis very much remains either a want-choosing cipher as in mechanism, or the bearer or instrument of the system as in the old biology of species. A strong doctrine of individualism must have reference to some form of revelation - God speaking to or through persons. The consequence of not taking seriously or recognizing the revelatory moment in legal systems is that Luhmann's construction of autopoietic law lacks a strong doctrine of individuals, which the common law, in common with a wide range of both secular and religious legal systems, at once cultivates and requires.

The ordinary meaning of revelation requires some version of God speaking directly to (or through) a legal person (or persons). I accept the ordinary meaning, with the caveat that it is incumbent upon the receiver of revelation to say what she means by "God." The social study of religion as ideology, invented by Hegel in his Lectures on the Philosophy of Religion ${ }^{122}$ and elaborated by Weber in The Protestant Ethic and the Spirit of Capitalism, ${ }^{123}$ picks up the thread of analysis where the "believer" stops saying what she means. Sociology can then trace the value-neutral, analytic continuation of terms left undefined by doctrine back into the heart of doctrine. Thus reworked, the sociologist is able to understand the relations between doctrine as an ex-

121. Not all have been guilty, however. Montesquieu, whose relations with the Enlightenment were ambivalent, to say the least, invented the sociological method of spirit ("esprit") precisely in order to use Enlightenment techniques to study the worlds created by religions. Hegel fashioned Montesquieu's discovery into a powerful analytic tool of general applicability in his Phenomenology of Spirit ("Geist" is "esprit"). Hegel's intricate studies of the worlds created by spirit (or ideology, in Marx's view) are scientifically unsurpassed. See, e.g., G.W.F. HEGEL, The Spirit of Christianity and its Fate (Geist des Christentums und Ihre Schicksal), in EARLY ThEoLOGICAL WRITINGS, 182-301 (1948).

122. G.W.F. Hegel, Lectures in the Philosophy of Religion (P. Hodgon ed. 1984) (first published in 1832).

123. M. Weber, The Protestant Ethic and the Spirit of Capitalism (1958) (first published as DIE PROTESTANTISIHE ETHIK UND DER GEIST DES KAPITALISMUS in 1904-1905). 
pression of values and the system of interaction instantiating the values.

American jurisprudence has overt revelatory moments, such as the doctrine of the Founders in constitutional law. ${ }^{124}$ Judicial discretion also resembles revelation - the reference of a decision to the "feel" or "temperament" of the decisionmaker, rather than to a series of prior decisions. ${ }^{125} \mathrm{My}$ thesis does not depend on these. Covert revelation is embedded in the structure of common law pragmatics: the status of the person vis-à-vis the norm and the norm vis-à-vis the person. Norms are revealed to decisionmakers through ordinary interaction (ordinary persons too are decisionmakers). The source of revelation is character manifest in interaction; the text of revelation is case law, understood as a record of exemplary interactions. Common law revelation thus has two moments: the orientation toward the norm of each individual applying it, and the reference in the norm to the selves disclosing themselves in prior applications. Revelation can thus be found in the focus of the common law on the individual case and in the character of persons making each case individual.

\section{CONCLUSION}

One may trace the casuistic and explanatory inadequacies of Luhmann's version of autopoietic law to one of two sources. Either scientific models themselves cannot fully convey the potential of law for governing human relationships or the autopoietic lawyers have not sufficiently mastered the epistemological subtleties of the new science from which they draw their model. I am not sure which is the case, since the new sciences of biology, psychology, and physics today are themselves similarly afflicted by terrible uncertainty.

One point is clear. If Luhmann wishes to be consistent with the methodological premises of autopoiesis, he should not want to claim validity for autopoietic law on the ground that it describes some legal system somewhere, just as the common law describes a possible legal system. ${ }^{126}$ The validity that rests on the description of possible facts is positivist validity. Luhmann's step away from positivism aims to place the model of autopoietic law within an evolutionary framework. Autopoietic law appears only after the social system has evolved suffcient functional differentiation to support an autonomous autopoietic legal subsystem. The model of autopoietic law thus becomes possible

124. See S. LeVinson, Constitutional Fatth passim (1988).

125. See Yablon, Justifying the Judge's Hunch: An Essay on Discretion (1989) (unpublished manuscript); cf. Weisberg, Judicial Discretion, or the Self on the Shelf, 10 CARDOzo L. REv. 105, 107-08 (1988) (applauding Justice Brennan's credo that the judge necessarily instantiates personal values in decisions).

126. Karl-Heinz Ladeur's extremely rich paper explores this theme. See pp. 242-82. See also supra note 50. Like Patrick Nerhot, Ladeur would be delighted by the common law. See supra note 16. 
at a certain moment in the evolution of the social system. Luhmann's general model of law includes all possible forms of the legal system, each appropriate to a different stage of social evolution. Luhmann thus anchors his positivism in a naturalistic evolutionary framework, where one observes (as in all naturalisms) all possible legal systems spread out over evolutionary time. ${ }^{127}$

Luhmann's recourse to naturalism in order to rescue autopoietic law from positivism misconstrues the method of the modern sciences of the individual. The conversation that is at the heart of that method requires that all possible legal systems be possible at one moment, not just in retrospect spread out over evolutionary time. Indeed such evolution as there may be favors increasing the instantiation of possible legal systems at a single moment.

Luhmann's methodology has the consequence that any single legal system he describes instantiates only one characteristic, such as autonomy. Either a legal system is the differentiated subsystem of a highly evolved social system - the sophisticated autopoietic law of an advanced industrial democracy - or it is a primitive, fundamentalist legal system coordinate with the entire social system. The legal system cannot be both at once.

Yet real modern legal systems exhibit all sorts of characteristics that, in principle, contradict each other. The American legal system uses the common law in some moments; it is positivist at other moments. It uses still other forms of jurisprudence we have only just begun to fathom. It is likely that no one model accurately describes any real legal system. Instead, one must look to the models as different expressions of values every legal system must at least consider. If a legal system insists on expressing only one value to the exclusion of others, then the others avenge themselves upon the jurisprudence of that system in the form of dilemmas, exceptions, and threats to the integrity of the system. ${ }^{128}$

Every legal system must principally reckon with dynamism, because every legal system must fulfill different and often conflicting goals and values, including the welter of values glossed by the notion of individuality. The model of the common law is superior to Luhmann's model of an autopoietic legal system only if it more successfully reckons with dynamism. The energy that some legal systems pour into remaining static does not create stasis, only dynamism in forms the legal system cannot use or comprehend.

Not every contributor to Autopoietic $L a w$ is as concerned as Luhmann with the value of autonomy. Not a single contributor, in-

127. I owe the thought about evolutionary time to a private conversation with Drucilla Cornell.

128. See, e.g., J. Dawson, THe ORAcles of THE LAW 503 (1968) (recourse to the case method in Continental systems). 
cluding Luhmann, is content to sacrifice the dynamism of autopoietic law to positivism and naturalism. The book is a testament to the interest legal theorists all over the world are showing in dynamic jurisprudence, and the relations of dynamic jurisprudence to individuality and community. Autopoietic law sharpens our understanding of these new and exciting prospects in legal theory, though it comes to us burdened with the special problems and perspectives of Luhmann's tradition.

We have our own special problems and perspectives. Any American reader who has a "conversation" with the essays in Teubner's collection will better understand the problems and perspectives of our tradition, and the enhanced possibilities for all traditions that modern legal theory is creating. 


\title{
THE RIGHT TO DISOBEY
}

\author{
Joel Feinberg*
}

CONFLICTS of LAw AND Morality. By Kent Greenawalt. New York: Oxford University Press and Oxford: Clarendon Press. 1987. Pp. ix, 383. Cloth, \$32.50; paper, \$12.95.

It is now widely agreed that a person can be morally justified in breaking a law, even a valid law in a democracy whose institutions are by and large just. There is much less agreement, however, about the sorts of considerations that constitute good moral reasons in support of disobedience. There are a variety of situations in which a person might think himself morally justified in breaking a law, and it is a distinguishing merit of Professor Greenawalt's impressive book that it discusses not just "civil disobedience" (the favorite topic of the 1960s), but all of the other categories of principled disobedience, too - from violent confrontation to conscientious objection, from forced choice of the lesser evil to jury nullification. But if there are moral reasons that tend to justify disobedience in special circumstances, it is usually an uphill struggle to find such justification, since there are also a number of weighty considerations supporting a duty of obedience - reasons that exert a relatively constant and substantial force against a claimed moral right in particular circumstances to disobey. Greenawalt has catalogued the reasons on both sides and given rough assessments of their respective weights when they are involved in a citizen's decision whether to obey. He concludes, among other things, that there are almost always powerful reasons for obedience, but that there are some infrequent situations in which citizens have even more powerful reasons to disobey.

To a large extent, then, Conflicts of Law and Morality is an extended essay in moral philosophy. The question, "Is it ever morally right (justified on balance) to disobey a law, and if so, under what conditions?" appears exactly the same in form as the moralist's question, "Is it ever morally justified to break a promise, tell a lie, inflict pain on others, etc., and if so under what conditions?" The answer to the former question, I would think (and Greenawalt agrees), is that disobedience can be morally justified, but only when the weighty reasons that tend to support a moral duty of obedience are outweighed in a particular set of circumstances by even weightier reasons that support a moral duty (or at least a moral right) to do something inconsis-

* Professor of Philosophy and Law, University of Arizona. B.A. 1949, M.A. 1951, Ph.D. (Philosophy) 1957, University of Michigan. 
tent with obedience. The answers to the parallel questions about lying, promise breaking, etc., have the same form: One can justify telling a lie, for example, but only when the normally powerful reasons that tend to support a duty of veracity are overridden in a particular set of circumstances by even more powerful reasons supporting a moral duty (or at least a moral right) to do something inconsistent with telling the truth. Whether a moralist, in either case, can give a more precise answer than this to the general moral question is one of the nagging perplexities that is not quite laid to rest by this book.

A large part of Greenawalt's book is addressed to problems of individual citizens who are faced with apparent conflicts between the claims of morality and law; but another large part of the book raises moral problems from a legislative perspective, asking what legal mechanisms can be designed for the treatment of lawbreakers whose disobedience can, at least to some degree, be morally justified. I found the concluding section of the book, entitled "Institutions of Amelioration," to be the most suggestive part. Greenawalt discusses in illuminating and persuasive ways the necessity defense (a "general justification"), conscientious objection and how the law should accommodate it, discretion not to arrest or not to prosecute, judge and jury nullification, and pardon as techniques for responding to lawbreakers who exhibit a genuine and plausible moral conviction that their disobedience was morally justified. The possibility that some morally justified acts of disobedience might be (or with legislative action, become) legally justified as well raises some terminological confusions. If the act in question is in fact legally justified, then it is not an act of disobedience at all, not an instance of lawbreaking. After all, we do not call killing in self-defense "justified lawbreaking"; we call it "justified killing" and deny that it is lawbreaking at all. One way out of this merely terminological muddle is to adopt Mortimer and Sanford Kadish's usage of the term "rule-departures"' instead of "lawbreaking," so that legally unjustified rule-departures are acts of lawbreaking, but legally justified rule-departures are not.

\section{The Individual CtTizen's Moral Problem}

Early in the book, Greenawalt draws on certain nonlegal examples of rules from games, private clubs, and the like to illustrate how "mandatory rules may do less than demand behavior they seem to require" (p. 7). By "demand" Greenawalt means "seriously claim[] obedience" (p. 6), so his view appears to be that the people subject to the rule are sometimes not unqualifiedly morally bound to obey, "[s]ince a general moral requirement to obey is unlikely to be broader than the law's demand for obedience" (p. 6). One of Greenawalt's

1. M. Kadish \& S. Kadish, Discretion TO Disobey (1973). 
nonlegal examples (with many obvious legal analogues) is a club's rule specifying certain conduct as a condition of membership in the club but not as a serious unconditional demand. Legal analogues include power-conferring (but not duty-imposing) rules. The law does not demand that you make a will but only that if you choose to make a will you must take certain steps if you are to be successful. (Similarly, the club rules do not demand that anyone remain or become a member.)

Greenawalt's most interesting example, however, is drawn from the rules of basketball which seem to wink at "acceptable fouls" in certain circumstances, and their analogues of "acceptable breaches of legal duty":

At certain points in a game, strategy dictates committing fouls that referees will call, and experienced players know when such fouls should be committed. As long as the fouls are not too flagrant, they are considered a normal part of the game ... . The "sanctions" applicable to such fouls ... are not severe enough to stop their intentional commission, and it is generally felt that were sanctions severe enough ...., the game would be less interesting, particularly because it would reduce the chance of a losing team catching up in the final minutes. [p. 10]

These rules, then, can plausibly be interpreted as merely stating the price that must be paid for an "infraction." If you wish to interfere in certain ways with an opposing player, the price is two foul shots. A similar way of interpreting criminal statutes is normally implausible, ${ }^{2}$ but Greenawalt argues that there are examples (which I will come to shortly) that approximate the basketball model. In both cases the theorist must explain how we can say what the rules really demand when "the proscriptive language of the rule book cannot be taken at face value" (p. 11), and the answer is that to speak of what the rule demands is shorthand for speaking of "what is demanded by the people concerned with the rules" (p. 11) - the rule makers, referees, opposing players, and spectators.

Greenawalt's example of "acceptable breaches of legal duty" analogous to acceptable fouls in basketball is an imaginary statute that makes gambling for money by "any person" a Class A misdemeanor. He imagines that the legislative majority, wishing to deter and penalize only professional gamblers, "but believing that a law cast in those terms would be too difficult to enforce and having confidence in the state's enforcement officials [and their prosecutorial discretion], adopt[s] the broader prohibition whose terms where [sic] designed to reach gambling between friends as well" (p. 12). After a time, the prosecutorial policy of not bringing charges against amateur gamblers becomes well-known and generally approved, so that "to say the "law demands' that people refrain from gambling would be artificial and excessively formal" (p. 13).

2. See H.L.A. HART, The CONCEPT OF LAW 39 (1961). 
In clear cases, it would be a mistake to say that an intentional foul in the last minutes of a basketball game by a player on the team that is behind, is an instance of justified disobedience to the rules, or that a friendly game of poker in a private living room is a deliberate and justified act of disobedience to the criminal statute, for they do not defy what the rule actually demands but only what it appears to require. But it is easy enough to tamper with the relevant variables, as Greenawalt acknowledges (pp. 13-14), so that the expectations of the relevant parties are mixed or unclear as to legislative intent, enforcement policy, and appropriateness of prosecution. In those cases (which may well include actual as well as hypothetical examples) there is simply no clear answer to the question of what the law demands.

In Part II, Greenawalt surveys the leading categories of reasons proposed by political philosophers in support of a general moral obligation to obey valid laws in a generally just democracy. ${ }^{3}$ (All bets are off in a totalitarian state like Nazi Germany.) Chapter four, the first chapter in this section, argues subtly but persuasively that a general duty to obey does not follow from the legitimacy of the government that makes and enforces the law, at least not as a matter of direct conceptual linkage. Chapter five discusses the most famous theory of political obligation, that which derives the moral obligation of obedience from the consent of the governed and the associated promise to obey valid laws. This historically dominant theory, whose leading spokesman was John Locke, ${ }^{4}$ has fallen on hard times recently, ${ }^{5}$ and Greenawalt gives it little encouragement. He undermines the Lockean idea of tacit consent, and concludes, after a long and careful discussion, that "many persons do apparently have promissory obligations to obey laws and other rules but ... on no plausible account have all or nearly all citizens or residents of liberal democracies promised to obey" (pp. 62-63). Even those who have undertaken to obey by explicit oath or "in a promiselike way" (p. 63) often do not become morally obligated in a sweeping fashion because of defects in their promises, such as duress. Greenawalt acknowledges, however, that proper promises can generate substantial moral reasons for obedience, and that there is no reason in theory why the state could not come to rely more on explicit promises to generate moral obligations of obedience in its citizens (p. 87). Nevertheless, he concludes, there are powerful reasons to oppose enforced programs of oath taking as a means of providing a moral sanction for law enforcement: First of all,

$\ldots$ an unqualified oath to obey all laws on all occasions is not one that can sincerely be given by thoughtful persons. Finding language that is

3. For another recent work that covers this ground, see A. Simmons, Moral Principles and Political Obligations (1979).

4. J. Locke, Two Treatises of Government (P. Laslett rev. ed. 1963) (3d. ed. 1698).

5. A. SIMmONS, supra note 3 , argues very effectively against Locke. 
less absolute but clear in its significance and comprehensible to ordinary persons is virtually impossible. We would be left with some vague undertaking to be law-abiding. [pp. 86-87]

Secondly, while some might be led by their promises to be more lawabiding, others would understandably be offended by the pressure to promise. (Asked once why he should object to taking a loyalty oath given that he was in fact loyal, a prominent philosopher asked mockingly why his wife, who is certainly faithful, should object to taking an oath at the start of each of her dinner parties promising that she will not commit adultery with one of the guests!) 6 Finally, "extensive use of oaths and promises," Greenawalt says, "risks devaluing the currency" (p. 87). If some might take their duties of obedience more seriously, others might take promises less seriously, and others might come to underestimate nonpromissory bases of moral duty.

None of the other standard theories of the moral foundation of a duty to obey the law succeed in establishing a set of reasons which apply to all possible instances of law-breaking. There is a general moral duty of "fair play," for example, that is violated even by criminal acts that do not have harmful consequences on balance. Instances of "free-riding," for example, make possible a gain for the lawbreaker that is possible only because other riders honorably forbear from taking similar advantages for themselves. In these cases, even when the honorable parties are in no way injured by the free-riding, they have been taken advantage of and treated unfairly. There are indeed many examples of legal disobedience that do exploit unfairly the law-abiding behavior of others. Most traffic infractions provide one class of examples. Income tax evasion provides another. But too many counterexamples exist for there to be a perfectly general obligation of obedience derived from the basic moral obligation of fair play. There are many types of cases where violating the law doesn't take advantage of anyone, and since the element of taking unfair advantage of the compliance of others is not involved necessarily in every instance of lawbreaking, "fair play" is by no means a perfect moral model. ${ }^{7}$ Running a red light on empty streets late at night under perfect conditions of visibility is one example, and such "victimless crimes" as smoking marijuana and cohabitation are others. In other cases, there is a clear moral duty to obey the law not simply because it is the law, but because there is a prior moral duty not to inflict on others the harm that is forbidden by the law. Yet, even much wrongful law-breaking of that class cannot be thought of as exploitative of other parties who are not its victims. When $A$ rapes $B$, may all the rest of us males complain

6. Informal conversation with the late Professor Curt John Ducasse, Brown University (approximately 1955 ).

7. Here I draw on my own work. See. e.g., Feinberg, Civil Disobedience in the Modern World, 2 HumanITIES IN Socy. 37, 54 (1979), reprinted in Philosophy of LaW 129, 138-40 (J. Feinberg \& H. Gross eds. 3d ed. 1986). 
that $A$ took unfair advantage of our compliance with the rape law to benefit at our expense? When $B$ murders her husband in a fit of wrathful jealousy, may all the other married people complain that she was able to get her way only because of their forbearance, that it is unfair to them that she acted on her wrath while they repressed theirs? Not very likely.

Greenawalt agrees with this conclusion after his own much more thorough examination of the duty of fair play, which he claims plausibly to be a "significant source of moral duty to obey laws, although it does not support a general obligation to obey all laws" (p. 153). That conclusion is similar to the conclusion of his discussions of the other traditional grounds for a moral obligation of obedience (promise, social utility, gratitude, the natural duty to promote just institutions). None of these theories establish "any single ground of duty to obey all laws, or all just laws, on every occasion of their application," but the collection of them establishes "multiple grounds for obedience in various circumstances" (p. 207), and there are some rare circumstances in which none of them provides a very forceful reason in support of a moral duty of obedience. In these latter circumstances, therefore, provided there are independent moral reasons of relatively substantial weight to do what is forbidden by the law, there may be overall moral justification for disobedience.

The more philosophically interesting problems regarding a duty to obey, then, are typically raised by conflicts of moral reasons, where acknowledged moral reasons tending to support a duty to obey are opposed by other acknowledged moral reasons tending to support a duty (or in some cases merely a right) to do something inconsistent with obedience. Greenawalt devotes Part III, and particularly chapter nine, "Resolutions Among Competing Moral Grounds: The Absence of Clear Priorities," to a consideration of these conflicts. The conflicting reasons are easily identified. They are all the ordinary moral principles that provide the familiar reasons underlying our moral duties. Since there are a plurality of such reasons, no one of them, considered in the abstract, can be a necessary condition for moral duty. Moreover, since more than one of these principles can be applicable and since sometimes they exert their weight on opposite sides of the scale, no one of them considered in the abstract is always a sufficient condition for moral duty. All a moralist can do with any certainty, then, is to provide "signposts to identify critical features" (p. 207). These will include such familiar moral principles as those enjoining promise keeping, truth telling, and benevolence, as well as more subtle principles requiring fair play, mutual aid, and promotion of just institutions.

Since these principles can conflict, some writers speak of them as imposing "prima facie obligations" (PFOs) - considerations that generate obligations proper unless some other PFO, or combination of 
PFOs, with more weight in these circumstances, counterbalances them. ${ }^{8}$ Thus, if a person has a PFO to do $A$, then he has a moral reason to do $A$ which is such that unless he has a moral reason or combination of reasons not to do $A$ that is at least as strong, then not doing $A$ is wrong, and he has an actual obligation to do $A$. Greenawalt wisely avoids speaking of prima facie obligations, partly because his concern is not only with moral obligations but with the moral preferability of actions that are not morally obligatory (acts of supererogation). Nevertheless, his complex pluralistic view of reasons leads him (like the writers who speak of PFOs) inevitably to use the metaphor of balancing. When reasons of acknowledged relevance sit in both pans of the balancing scale, we must find a way to determine which has the greater weight in the circumstances. I think a more fitting metaphor would be that of a decision maker who lacks scales but must do his weighing intuitively, first by lifting one object and then the other. In any case, the weigher has no simple formulas to apply which tell him that one kind of consideration is invariably heavier - or even usually heavier - than the other kind.

One might complain that the plight of the weigher is not as dismal as this picture suggests, that there are simple rules of thumb that put different considerations into some kind of priority relation. But Greenawalt easily finds exceptions to the most commonly proposed of these, that which gives automatic priority to the law's moral claim to obedience over any competing moral claim, and that which gives priority to the claims of justice over the claims of welfare. The moral philosopher and the legal theorist can help us make these difficult judgments of comparative "weight" by alerting us to the full variety of moral considerations that can be involved; by showing the various ways they apply and how their conflicts have been resolved in other circumstances; by exposing and helping to correct our prior biases, so that, like a rifleman who adjusts his aim to account for the wind direction and velocity, we can compensate for them; and especially by helping us determine to what extent, if any, the accustomed weight of a given kind of moral consideration is actually exerted in the case at hand. But in the end, "people facing decisions about obeying the law must do their uncertain best to take appropriate account of the relevant claims without plain rules of guidance” (pp. 222-23).

Greenawalt's discussions of civil (open and nonviolent) disobedience in chapter ten and violent disobedience in chapter eleven show how his "guidance" through the labyrinth of these personal moral problems, even without "plain rules," can be helpful. His analyses are informed and sophisticated, and his balance and common sense commendable, but the reader who expects more than Greenawalt's cautious methods permit will find no excitement here. On the other hand,

8. See Smith, Is There A Prima Facie Obligation to Obey the Law?, 82 YALE L.J. 950 (1973). 
one can never accuse Greenawalt of oversimplification. And the truth itself in this area, insofar as it can be expressed in general terms, may be so complex that it too is "unexciting."

\section{INSTITUTIONS OF AMELIORATION}

Can legal practices be designed which treat morally conscientious rule breakers with respect and appropriate leniency while at the same time not weakening the public's general fidelity to law? Greenawalt devotes the final section of his book, four chapters in all, to this question, which he addresses with his customary thoroughness. I will discuss here his recommendations with respect to only three practices of accommodation from among the many he discusses, namely the general "necessity" justification, the exemption for conscientious objection to war, and jury nullification.

The general justification defense in the criminal law has functioned as an open-ended exception to liability. The law does lay down some specific justification defenses (self-defense, for example), but the necessity defense, in effect, refers to any other moral justifications (left largely unspecified) that similarly ought to exempt the actor from liability. Greenawalt chooses as his example of a formulation of the defense the influential section 3.02 of the Model Penal Code, the relevant parts of which are as follows:

Conduct which the actor believes to be necessary to avoid a harm or evil to himself or to another is justifiable, provided that:

(a) the harm or evil sought to be avoided by such conduct is greater than that sought to be prevented by the law defining the offense charged; and

(b) neither the Code nor other law defining the offense provides exceptions or defenses dealing with the specific situation involved; and

(c) a legislative purpose to exclude the justification claimed does not otherwise plainly appear. ${ }^{9}$

With such a defense, for example, one can be acquitted of car theft for having "borrowed" another's car without permission in order to rush a heart attack victim to the hospital when no other mode of instant transport was available, or for exceeding the speed limit on the way to the hospital. That the otherwise criminal act was in fact necessary to avoid the evil is not required by the defense provided the defendant's belief that it was necessary was genuine, but that the evil sought to be avoided (likely death of the heart attack victim) was in fact greater than the evil sought to be prevented by the law (property loss and increased risk of accident), must be proved to the jury's satisfaction. The defendant's honest belief in the correctness of that comparative evaluation is not sufficient.

No reasonable person would want to punish the emergency 
speeder and other clearly justified lawbreakers, so Greenawalt is generally in favor of rules like that exemplified by the Model Penal Code. He rejects the argument on the other side that rare cases of emergency "necessity" can be "trusted to the good sense of prosecutors and judges," citing the need for "a safeguard against prosecutorial abuse" (p. 287). Anyway, even when enlightened prosecutors do not bring charges, genuinely justified rule-breakers "should have legal confirmation that they have acted appropriately" (p. 287). But there are controversial cases of apparently forced choices of a lesser evil (mostly hypothetical cases) that are much more difficult than the standard textbook examples, and which create serious difficulties, in particular for the Model Penal Code's formulation. Greenawalt is undaunted by these difficulties, but he does admit that they seem to call for some "modest additions to statutory language" (p. 306). Most of these diffculties stem from the Code's "undilutedly consequentialist" approach to the assessment of evils (p. 293).

A "deontologist" in moral philosophy would insist that a person might indeed violate the law in order to bring about the lesser of the harms he is forced to choose among, such as causing harm to one person instead of two, and yet be morally unjustified in doing so. Perhaps he had some special responsibility to protect that one person from harm and should not have treated him as just another number in his calculations. Perhaps that person is a close friend or family member, one's spouse, or parent, or child, and the other two are strangers. If we are to give people with whom we have special relationships a greater weight in our moral deliberations, then the tidy determinateness of the Model Penal Code rule will be shattered and the use of numbers to weigh evils will begin to appear arbitrary. So one can understand part of Greenawalt's motivation for maintaining the consequentialist approach of the Code, regardless of the deficiencies consequentialism might have in moral philosophy. Moreover, he writes, "One underlying principle of the criminal law is to encourage people to respect the fundamental interests of strangers, and the creation of ad hoc exceptions justifying special protection of friends and family members would be ill-advised" (p. 293). (He makes no more than implicit mention in this connection to special contractual obligations of protection, e.g., those of nurses or bodyguards.) The argument on the other side is that the whole point of the necessity defense is to give proper respect in our legal judgments to the requirements of morality, and this goal is not achieved by a legal requirement that demands that a person do what he is not truly morally justified in doing.

Another class of cases in which the comparative harms approach of section 3.02 yields highly controversial judgments are those in which the defendant is charged with homicide, and the possibility of a consequentialist justification of his killing flies in the face of widely 
held convictions that certain types of intentional killing are inherently wrongful whatever their consequences, and are therefore categorically prohibited. The Roman Catholic doctrine of "double effect" permits a person to cause another's death as an unwanted but virtually certain byproduct of an act intended to save others, but not as a deliberate means to an end, however worthy the end. Thus, "townspeople may not kill their mayor (who is in hiding) under the credible threat by a foreign invader that everyone in the town will otherwise be destroyed, nor may a surgeon kill a healthy person to acquire body parts whose transplant will save the lives of five others" (p. 295). The surgeon will not, and surely should not, win legal vindication of his judgment of moral justification (though it is not clear why he doesn't qualify for justification under the Model Penal Code rule). But the townspeople, unjustified by the doctrine of double effect, would nevertheless have a potential justification under the Model Penal Code rule. Moral absolutists, in short, would be outraged at a legal rule which rejects their deep moral convictions.

Is there any way of redrafting the rule that would be less offensive to moral absolutists? One way that Greenawalt mentions is to give some flexibility to judges and juries "to reject a claim of justification if they thought fundamental moral standards had been transgressed" ( $p$. 295). But that could be even more unfair to defendants who hold honest consequentialist moral convictions than the Model Penal Code consequentialist rule would be to moral absolutists. If a consequentialist killer who is morally justified in his own eyes should happen to find an absolutist jury he will be severely punished for his convictions, whereas under the Model Penal Code rule no absolutist will even be tried much less punished for doing anything required by his moral convictions. On the other hand, juries seem to need some way of rejecting the Model Penal Code's comparative harm approach when it seems to justify defendants like our hypothetical transplant-surgeon who have "clearly transgressed accepted moral standards without a sufficiently overwhelming reason" (p. 295). Greenawalt suggests appending to the Model Penal Code rule the independent requirement that the act "justly respect the interests of everyone involved" (p. 296). This would have the additional advantage of requiring the use of fair selection procedures, like lotteries, by those who would kill in those desperate emergencies which require that some people be sacrificed so that a greater number might survive, as in the famous lifeboat cases, Regina v. Dudley and Stephens ${ }^{10}$ and United States v. Holmes. ${ }^{11}$

In chapter fourteen, "Conscientious Objection and Constitutional Interpretation," Greenawalt considers the multifaceted question of "whether, and when, society should excuse people from obligations

10. 14 Q.B.D. 273 (1884).

11. 26 F. Cas. 360 (C.C.E.D. Pa. 1842). 
because they strongly feel that performing them would be morally wrong" (p. 311). As the chapter title indicates, he considers this question both as a problem for legislators deciding what new legal defenses to create and also as a problem in American constitutional law for courts deciding how to interpret the rights we already have. I will discuss here only Greenawalt's treatment of the legislative problem, taking exemption from military service as an illustration.

Not all people who think that military service is morally wrong can be said to be "conscientious objectors." The genuine conscientious objector believes that entering military service (or accepting combat duty, if that is what he objects to) would be a "grave moral wrong." Part of the test for gravity, Greenawalt suggests, is "what the objector thinks he should be willing to suffer rather than commit the act" (p. 313). The person who has a moral objection to military service but thinks that in his own case such service would be morally preferable to going to jail is not "conscientious" in this sense. The objector who believes that "one should submit to penalties that society (or any decent society) has deemed appropriate" rather than perform the act is conscientious in the appropriate sense (p. 313). (Greenawalt doesn't notice the makings of a paradox here. His view seems to imply that only those who can demonstrate their conscientiousness by submitting to punishment deserve exemption from punishment.) ${ }^{12}$

Respect for conscientiousness dictates some special treatment for the conscientious objector, but distributive justice would be violated if the conscientious objector were exempted altogether from onerous burdens that others must shoulder. After all, people who are physically unable to shoulder the burdens of combat are given desk jobs rather than being excused altogether from service, and the conscientious objector should be treated like them, since their moral convictions in a parallel way render them "incapable of combat." Taking justice seriously requires equalizing the burdens as much as possible. Criminal punishment would do this but at the cost of inappropriately severe symbolic condemnation and the waste of social resources. So productive alternative service seems to be the answer.

12. The late Cambridge philosopher, C.D. Broad, actually embraced this paradox in his contribution to a symposium in the 1930s. See C. BROAD, Ought We to Fight for Our Country in the Next War?, in ETHICS AND THE HISTORY OF PHILOSOPHY 232 (1952). Broad argued that it is virtually impossible for a person to know (or for another to know about him) that one of his actions (e.g., his refusal to serve in a war) truly is conscientious. Indeed, Broad claims, the truly conscientious person is likely to have the strongest doubts about the purity of his own conscientiousness. Moreover,

[p]lainly there is a prima facie obligation not to put yourself in this situation of one-sided dependence on what you must regard as the wrong actions of people who are less virtuous or less enlightened than yourself. This complication would be avoided if the conscription-law imposed the death penalty for refusal to undertake military or other war service. I am inclined to think that this ought to be done, and that really conscientious objectors to military service should welcome it.

P. 241. 
The main problem for schemes of alternative service is that of selecting out, from those who morally disapprove of military service for one reason or another, those who should be offered alternative service. Greenawalt argues effectively against various ways of employing a religious test - requiring membership in a traditionally pacifist sect, or "acceptance of a Supreme Being," or fear of "extratemporal consequences."13 Greenawalt does not strongly object to exemptions for sincere pacifists, whether religious or not, or for those who object on religious or other grounds to a particular war (though "[they] much more closely than pacifists resemble persons who have ordinary political objections to particular wars ... [and] are more difficult for others to identify") (pp. 326-27).

The original contribution of Greenawalt to the debate, however, is not his criticism of other principles of selection but his proposal of a scheme of self-selection as an alternative which "circumvents all the difficulties that accompany even the best tests of eligibility":

If a draft is reinstituted, Congress should establish an alternative civilian service that anyone could choose. Since the draft's aim is to get soldiers, the conditions of civilian service should be set so that the great majority of people will prefer military service, but the conditions should be no more onerous than are needed for this objective. Civilian service could carry substantially less pay and subsidiary benefits or be for a longer period of time, or both. If a lottery were used for military service, young men (and perhaps young women) might choose between a certainty of two years of civilian service and a chance of two years of military service. For a more nearly universal draft, the choice might be between two years of military service and two and a half or three years of civilian service. [p. 327; footnotes omitted]

Greenawalt's voluntary self-selection scheme has much to recommend it, but it is not a better way of selecting out the genuinely conscientious objectors. Rather it is a system with wider objectives, one of whose incidental advantages is that all of the genuinely conscientious objectors may exempt themselves from military service, though not all of those who will exempt themselves will be conscientious objectors. Many will have less grave moral objections to military service; some will simply dislike such service so intensely that they would prefer alternative service for less pay and a longer period. The great merit of the proposal is that it does justice to the conscientious objectors in the most certain and economical way while raising an army of just the size policymakers think is needed. And above all, "[i]t eliminates the incredible practical problems of accurately identifying sincere conscientious objectors. ... [ [and n]o one in the military could feel unfairly treated by the choice of others to do civilian work, as long as he or she could have made the same choice" (p. 327).

13. The phrase is Jesse Choper's. See Choper, Defining "Religion" in the First Amendment, 1982 U. ILL. L. REV. 579, 597-601 (1982). 
There will be a class of extremely sensitive conscientious objectors, unmentioned by Greenawalt, who will still exclude themselves, but there is probably no helping that. I refer to those who are so opposed to the very existence of a standing army that they will have nothing to do with any system of conscription, fair or not, which supports a fighting force. These persons will refuse both military and civilian service. I suspect that the small number of objectors in this category will welcome the opportunity to dramatize their opposition by undergoing penal servitude for a comparable term. Surely, it would be prima facie unfair to impose a draft on everyone else, and leave them as they were, free to avoid their share of the burdens. Presumably, the class in question, those with especially sensitive consciences, would not wish to receive any kind of preferential treatment, so they might welcome an appropriate period of imprisonment (but for its inevitable stigma) as the least unacceptable form of "alternative service."

The status of jury nullification in common law countries is one of the law's most intriguing anomalies. On the one hand, juries have the unrestricted power, if they choose, to disregard the judge's instructions, and acquit a defendant even though they believe that the evidence shows beyond a reasonable doubt that he is guilty of the crime charged. Jury deliberations are secret; they are not subject to review after the trial; jurors may not be subjected to any penalty for dereliction of official duty; and acquittal verdicts may not be appealed or overturned because of the double jeopardy rule. On the other hand, juries are told that they have an unqualified duty to follow the judge's instructions and to decide on guilt or innocence according to the evidence. Each juror takes a solemn oath to do just that. So it appears that the law in a quite explicit way deliberately confers a power on juries to do what they have an equally explicit duty not to do.

Greenawalt's resolution of this puzzle is much the same as that of Mortimer and Sanford Kadish. ${ }^{14}$ A juror has no moral right to violate his solemn oath on the ground that there would be some unfairness in punishing the defendant even though he is plainly guilty, or because the juror disapproves of the statute the defendant is charged with breaking. Rather the jurors must place a substantial "surcharge" on departures from their official obligations. Conviction must seem more than unfair; it must seem unconscionable, a gross injustice given the defendant's undeniable moral right to do what he did. A single juror who makes these moral judgments can nullify the judge's instructions quite surreptitiously, so that no one will ever know what has happened. Sometimes, in morally desperate circumstances, that is what a juror should do, since secret nullification does less damage to a just institution (jury trials) than open and clear nullification would do.

As things now stand, conscientious jurors in morally difficult cases

14. M. KADISH \& S. KADISH, supra note 1, at 45-66. 
are in an unenviable position. "Because no one tells them under what conditions they may nullify the law, they are likely to feel themselves being pulled in two different directions, with the uneasy feeling that whatever they do will be wrong from some point of view" (p. 364). The Kadish-Greenawalt analysis of their moral plight, especially if it is uncommunicated to them by any legal authority, will not dissolve their perplexities or alleviate their discomforts. For that reason, Greenawalt is not content to leave things as they stand. He concludes his discussion by considering possible reform of the rules. But here too he finds a dilemma: "If jury nullification could be effectively discouraged, jury power to prevent injustice would be diminished. If jury nullification were formally approved, the proper authority of the written law might be undermined" (pp. 366-67). Nevertheless, Greenawalt is hopeful that language can be found that would "alert all jurors to the existence of the nullification power" (p. 367) but would warn them emphatically that it should be used only in the most extreme cases. "The gains in openness and consistency," he concludes, "should outweigh any harm from a slight increase in instances of nullification" (p. 367).

I suspect, however, that a stronger case could be made for the status quo, anomalous though it may be. If jurors know what a promise is, they know that it creates a moral obligation that cannot be overridden by the prospect of gain or the avoidance of minor harm or routine injustice, but only to avoid disastrous losses or unconscionably gross injustice. ${ }^{15}$ However, to make that implicit understanding explicit by means of official judicial instructions is likely to make the desperate option seem ordinary and one deserving of routine consideration in all cases. There is no foretelling, of course, what the actual effects of the proposed instructions might be, but there is a danger that explicit legal recognition of a moral right whose existence goes without saying would further distort juries' understanding of the nature and extent of that right. Anomaly cannot be eliminated in any case. A solemn oath with a vague exceptive clause will be at least as befuddling a basis for action as the deliverances of a juror's own conscience. Another implicit message to jurors that goes without saying is, "I never told you it would be easy."

It is not possible in a brief review of Conflicts of Law and Morality to do justice to the wide range of issues discussed in this large and comprehensive work. No facet of the conflicts between law and morality is left unexamined. There are clear summaries and transitions, and very useful "illustrations," specially marked and numbered, in the form of hypothetical examples and stories, most of which come from rule-governed practices outside the law. Numerous excellent works by

15. See Rawls, Two Concepts of Rules, 64 PHIL. Rev. 3 (1955); Feinberg, Duty and Obligation in the Non-Ideal World, $70 \mathrm{~J}$. PHIL. 263, 272 (1973). 
other authors exist on the subjects of this book's individual chapters, but I know of no book that is as good a guide to the whole area. 
Precedent In LAw. Edited by Laurence Goldstein. New York: Oxford University Press. 1987. Pp. xvi, 279. \$42.

In Precedent in Law, Laurence Goldstein ${ }^{1}$ has assembled a collection of essays dealing with the fundamental and pervasive phenomenon of precedent. ${ }^{2}$ Although not formally divided into sections, the essays fall into three basic categories: (1) essays providing an historical overview of the approaches to precedent; (2) essays concerning theories of binding precedent; and (3) essays on the less fundamental (though still very important) issue of how one actually reasons from prior cases, assuming that some version of the practice of precedent can be justified.

Goldstein's purpose in bringing together the works of the eight contributing scholars ${ }^{3}$ was "to produce a collection of essays that may be read with pleasure and profit by students, practitioners and, indeed, by anyone with an interest in the workings of the law" (p. vi). By thus limiting his goals, Goldstein easily achieves them; yet he also limits Precedent in Law's usefulness to the scholar. The essays focus on such different areas and work from such varying assumptions that the reader does not come away with any coherent sense of the role of precedent in legal theory. Although all of the essays address some aspect of precedent, it is difficult to find a theme that unifies them. A summary of the three essays dealing with the theory of binding precedent will illustrate this point.

In Theories of Adjudication and the Status of Stare Decisis (pp. 7387), Peter Wesley-Smith addresses whether strict stare decisis can be justified by either the declaratory or the positivist theory of decisionmaking. The declaratory theory views the common law as independent of the pronouncements of the judges: it is "unchanging and unchangeable in essential content" (p. 79). Given that it is the judge's duty to rule according to this eternal law and that previous judges may have erred, precedents under the declaratory theory can never be

1. Reader in the Department of Philosophy, University of Hong Kong. Among Goldstein's other works are Some Problems About Precedent, 43 CAMBRIDGE L.J. 88 (1984) and Four Alleged Paradoxes in Legal Reasoning, 38 CAMBridge L.J. 313 (1979).

2. As usually formulated, the notion of precedent is that like cases should be treated alike.

3. The contributors are: Theodore M. Benditt, Professor of Philosophy and Dean of the School of Humanities at the University of Alabama at Birmingham; Anthony Blackshield, Professor of Legal Studies at La Trobe University, Melbourne; Richard Bronaugh, Professor of Philosophy at the University of Western Ontario; Jim Evans, Senior Lecturer in Law at Auckland University, New Zealand; Neil MacCormick, Regius Professor of Public Law and the Law of Nature and Nations, and Dean of the Faculty of Law at the University of Edinburgh; Michael S. Moore, Robert Kingsley Professor of Law at the University of Southern California, and Professor of Law at the University of California, Berkeley; Gerald J. Postema, Associate Professor of Philosophy at the University of North Carolina at Chapel Hill; and Peter Wesley-Smith, Professor of Law at the University of Hong Kong. Pp. ix-x. 
strictly binding - they are good indicators of what the law is, but they are not the law and hence cannot command blind adherence. ${ }^{4}$ The positivist theory, on the other hand, views judicial pronouncements as law made by judges. This would, at first, seem to require that judgemade law be strictly followed; in fact, Wesley-Smith believes that the positivist theory can support vertical stare decisis. ${ }^{5}$ But what about horizontal stare decisis? It would appear that if a court declares that stare decisis is a rule of law, then subsequently that court is explicitly bound to follow its own precedents (p. 85). However, Wesley-Smith argues that "a court's authority to make law must be a continuing authority, which would be denied if a court were bound by its own decisions" (p. 82). He finds horizontal stare decisis as untenable as the idea that Parliament could bind itself for the future. ${ }^{6}$ To those who would argue that law can derive from a legal system's "rule of recognition,"7 Wesley-Smith responds that such a rule is nothing more than "the various criteria generally accepted as fundamental by the personnel of the legal system" (p. 86) and that the authority of stare decisis (like any rule of law) becomes uncertain when the personnel no longer agree that it is law. Thus, Wesley-Smith concludes, neither the positivist theory nor the declaratory theory can support the practice of stare decisis.

Theodore M. Benditt, in The Rule of Precedent (pp. 89-106), examines the theoretical basis of precedent from a different angle, asking how a rule of stare decisis can logically arise in the first place. After first analyzing various justifications for stare decisis, ${ }^{8}$ Benditt argues

4. P. 79. In another part of the essay, Wesley-Smith gives what might seem to be a different account of the declaratory theory: "[T]he judge searches the records, discovers the law previously recognized, declares and expounds it, and applies it to the dispute before him." P. 74. Although this statement suggests reliance on the rulings in previous cases rather than on the judge's own determination of the law, it assumes that the law is "recognized" (i.e., discovered) and not created.

5. Vertical stare decisis refers to "a court being bound by decisions of courts above it in the hierarchy." P. 81. Horizontal stare decisis refers to a court being bound by its own earlier decisions. See p. 82.

6. P. 82 n.46. But cf. Simpson, The Ratio Decidendi of $a$ Case and the Doctrine of Binding Precedent, in OXFord EsSAYS IN JURISPRUdence 148, 154 (A. Guest ed. 1961).

7. P. 85; see, e.g., Simpson, supra note 6 , at 154-55.

8. Benditt examines four such arguments. The first is that logical consistency demands that later cases be treated like previous similar cases. Benditt dismisses this argument with the observation that logical consistency merely demands that a reason be given that justifies the change in treatment. Pp. 89-90. The second argument addressed is the familiar one that justice requires that like cases be treated alike. The problem with this argument, according to Benditt, is that disparate treatment of similar cases means only that one of the parties is being treated unfairly the party whose case is decided wrongly, who can be the litigant in either the first or second case. P. 90. Third, following precedent promotes stability and certainty in the legal system. While acknowledging the value of stability, Benditt warns that "[t]he law cannot become entirely static"; flexibility is needed to meet inevitable social change. P. 91. The fourth argument for stare decisis applies when the prior decision was reached by "a more or less arbitrary drawing of lines for future reference." P. 92 (quoting Lyons, Formal Justice, Moral Commitment, and Judicial Precedent, 1984 J. PHIL. 580, 585). The argument for following precedent in such cases is 
that a rule of precedent evolves just like ordinary substantive rules of law: through "repeated, reinforcing judicial decisions" establishing a rule of, in this case, following past decisions (p. 97). The argument, in detail, runs as follows:

Suppose a rule of law favoring complainants in a given sort of case becomes established ... by a line of decisions in which each judge decides that the best reasons favor following the prior decisions [independent of the merits of each case]. Let us suppose further that in other sorts of cases judges have regularly followed prior decisions, and that as an upshot various rules of law have been established. An important by-product of this process is that a legal rule of precedent is likely to become established in the same way. It is easy to imagine it becoming both the accepted and expected practice of and among judges to decide cases by appeal to past decisions. Judges come to regard the following of prior decisions as appropriate for themselves and for other judges, and to think it wrong - legally wrong - to do otherwise. ... [W] [Wen this stage has been reached it is correct to say that a legal rule exists. [p. 97]

More important than the possible criticisms of this argument $^{9}$ is its strong positivist assumption: that judicial decisions, at least collectively and over time, make law. It is on this positivist assumption that Benditt bases his theory of stare decisis. Yet Wesley-Smith argued in the previous essay that positivism fails to support stare decisis. Clearly, the authors' theses conflict - yet, because they pursue different topics and because they fail to address directly each other's arguments, the extent and seriousness of the conflict and whether and how the conflict can be reconciled is left unclear.

The reader revisits horizontal stare decisis in Anthony Blackshield's "Practical Reason" and "Conventional Wisdom": The House of Lords and Precedent (pp. 107-54). Specifically, Blackshield examines how the House of Lords has historically dealt with its own precedents and the theories, new and old, of how to justify these approaches. In the nineteenth-century case of London Street Tramways, Ltd. v. London County Council, ${ }^{10}$ the House of Lords declared itself absolutely bound by its own prior decisions. The House aban-

that "the original decision constitutes a commitment, made to others, that future decisions in similar cases shall be made similarly." Id. (emphasis in original). Benditt likes this approach and thinks an analogous situation appears in cases where the previous decision is not arbitrary, but where the disagreement in society is so sharp that it might seem arbitrary. As he puts it, "the less the agreement on principles [in society], the more like an arbitrary commitment a judicial decision will seem." P. 92. Benditt's support for following precedent thus seems to be based on societal skepticism, namely "our (collective, though not individual) lack of certainty about the correctness of certain of the social and political principles we adopt." P. 92.

9. One difficulty is that it assumes (incorrectly) that judges can determine that the best reasons favor following past decisions without knowing the alternative, i.e, the arguments that go to the merits of the case. Yet if judges do consider the arguments that go to the merits and reject them in favor of following the prior decisions, then they - to some extent - have decided on the merits.

10. 1898 App. Cas. 375. 
doned this approach in 1966 by declaring that, while normally it would follow precedents, it would "depart from a previous decision when it appeared right to do so."11

One possible explanation for this history is that the House of Lord's approach to its own precedents is "not itself a subject-matter for precedent" (p. 110). By this view, the House's approach is considered a matter of "practice." Rules of practice are not the same as rules of law, though they can "harden into law and create new rules of law where no relevant rule existed before" (p. 110). In short, rules of practice appear to be law-like except that their application is, to some extent, subject to the discretion of judges. As Blackshield puts it, 'however firmly a 'practice' may seem to have hardened into 'law,' it is always open to courts to affirm that it was after all only a 'practice,' and thus to change it in circumstances where they would not be willing (or able) to change a rule of law" (p. 111; emphasis in original). However, as Blackshield points out, explaining the House's approach to precedent in this way does not fully account for the belief that prevailed during the London Street Tramways regime that the rule against self-overruling was legally binding and thus not subject to judicial discretion. Blackshield also seems unconvinced by the notion of a court's "inherent" power to regulate its own practice, though he fails to explain the theoretical basis of his objection.

Blackshield then considers explaining the House's approach to precedent in terms of a "constitutional convention." This differs from a "practice" in that a constitutional convention must

have about it a quality of moral restraint, importing (i) that the effect of the convention must somehow be to limit the exercise of power, and (ii) that observance of the limits imposed must be perceived not merely in terms of practical convenience, nor even of rational "principle," but as some kind of moral obligation. ${ }^{12}$

Although it may be easy to see the London Street Tramways rule as an

\footnotetext{
11. Lord Gardiner's announcement of the new practice reads:

Their Lordships regard the use of precedent as an indispensable foundation upon which to decide what is the law and its application to individual cases. It provides at least some degree of certainty upon which individuals can rely in the conduct of their affairs, as well as a basis for orderly development of legal rules.

Their Lordships nevertheless recognise that too rigid adherence to precedent may lead to injustice in a particular case and also unduly restrict the proper development of the law. They propose, therefore, to modify their present practice and, while treating former decisions of this House as normally binding, to depart from a previous decision when it appears right to do so.

In this connection they will bear in mind the danger of disturbing retrospectively the basis on which contracts, settlements of property and fiscal arrangements have been entered into and also the especial need for certainty as to the criminal law.

This announcement is not intended to affect the use of precedent elsewhere than in this House.
}

Practice Statement (Judicial Precedent), [1966] I W.L.R. 1234, 1234.

12. P. 144 (emphasis in original, footnote omitted). Just why a moral obligation cannot involve a rational principle is not explained. 
instrument of restraint, to view the Practice Statement rule that way requires a change in perspective. Instead of describing it as allowing departures from past precedent, Blackshield suggests that the Practice Statement is simply a less strict version of the London Street Tramways rule: The House of Lords will use this newly proclaimed power to overrule sparingly so that the judiciary will not usurp too much the functions of the legislative branch of government. ${ }^{13}$ The Practice Statement can thus be seen not as granting power to overrule, but as assuring that such power will be used within limits. As Blackshield observes, "[t]hese limits and assurances are precisely the stuff that constitutional convention is made of" (p. 144).

Since Blackshield defines a "constitutional convention" in terms of "moral restraint,"14 he must confront the fact that "[m]oral restraints on power-wielders are not intended for the benefit of other powerwielders" (p. 146) but rather for the "public good."15 Here, Blackshield is skeptical that either individual interests or the "public good" have ever been promoted by the House's strict adherence to precedent (p. 151). In the end, therefore, he views the attempt to conceptualize the House's approach to precedent as a "constitutional convention" as a theoretically unsound, though possibly convenient, "carpet" under which we can sweep our worries concerning its juristic status (pp. 15354).

Like the previous two essays, Blackshield's is internally coherent. The problem lies in relating it to the other essays, both those dealing with the same general subject and the others in the book. As Benditt does in his essay, Blackshield implicitly accepts a positivist view of law in his discussions of "practice" and "convention."16 Blackshield, unlike Benditt, does respond to Wesley-Smith's argument that a court cannot bind its successors, ${ }^{17}$ arguing that since it "depends on an inference from the nature of sovereign legislative power, this attempt to extend it to judicial power is probably more ingenious than persuasive" (pp. 137-38; emphasis in original). Here, however, Blackshield misses Wesley-Smith's point: that when the House overrules previous decisions it is exercising legislative-like powers. Thus, his response is insufficient. On the other hand, though Blackshield and Benditt both

13. See p. 144.

14. See supra text accompanying note 12 .

15. P. 148. Blackshield recognizes the difficulty in determining just what the "public good" refers to, but suggests that rather than responsiveness to public opinion, "the aspects of "public good' which have especial relevance and significance for judicial institutions may have to be found elsewhere, for instance in the need for protection of individual freedom." P. 149.

16. For Benditt's support of positivism, see supra note 9 and accompanying text. Although neither a "practice" nor a "constitutional convention" is "law," they both share with the law the characteristic of being created by judges, as opposed to existing eternally as in the declaratory theory. Pp. 110, 139-40; see supra note 4 and accompanying text.

17. See supra text accompanying note 6 . 
presuppose positivism, they do not even address the same issues. Hence, despite some tantalizing points at which the essays converge, these points are too few and not significant enough to add a unifying element to the essays.

It is even more difficult to relate these essays to the others dealing with different general areas. For example, in Precedent, Induction, and Ethical Generalization (pp. 183-216), Michael S. Moore attempts to solve two problems of generalization he finds in law, science, and ethics. The first problem concerns how to justify going from particular bits of evidence (e.g., past decisions, scientific data, or specific ethical judgments) to general rules. Moore's solution is, in short, to deny any need to justify the principle of induction separately from the justification of the particular rules sought to be established (pp. 196-97). To those who would object that the particular inductive arguments for the particular rules ultimately rely on some other inductive arguments, which in turn must rely on some other inductive arguments, and so forth, Moore responds that no starting point is necessary since new beliefs are justified according to their coherence with old beliefs (pp. 197-98). As for the second problem - which rule to generalize to when more than one fits the data - Moore argues that one should pick the rule that most coheres with other accepted beliefs (pp. 20609).

How Moore's arguments affect the theories in the three essays described above is not clear. What relation does Wesley-Smith's rejection of stare decisis have to the problem of induction? How does Moore's theory affect Blackshield's analysis, which assumes that "practice" and "convention" are both deliberately chosen and not "discovered" through a process of generalization? Moore and Benditt might seem to advocate similar theories ${ }^{18}$ yet, as it turns out, the similarities are superficial. Benditt assumes that judges can generalize from past decisions to form a rule of precedent, while Moore's whole essay focuses on the very process of generalizing. So again, significant debate on any single issue fails to materialize, and the reader is left wondering why these essays are in the same book.

The essays in Precedent in Law deal with numerous aspects of precedent, but the diversity of these works makes it difficult to relate one piece to another. Thus it is unlikely that the scholar will find more than a few of the essays useful. However, despite the lack of coherence among the contributions, Precedent in Law is still worth reading. The essays themselves are generally very good: well-organized, interesting, and accessible to the general reader. While the works have a

18. Both argue that what seems to be a special problem is not really so special. Moore claims that the process of induction needs no more justification than the particular rules sought to be established; Benditt argues that the rule of precedent does not need to be established any differently than typical substantive rules of law. 
theoretical emphasis, they also provide appropriate support for their theories. Precedent in Law's value is as an introduction to some of the historical and contemporary thinking on precedent.

- Erik G. Light 